
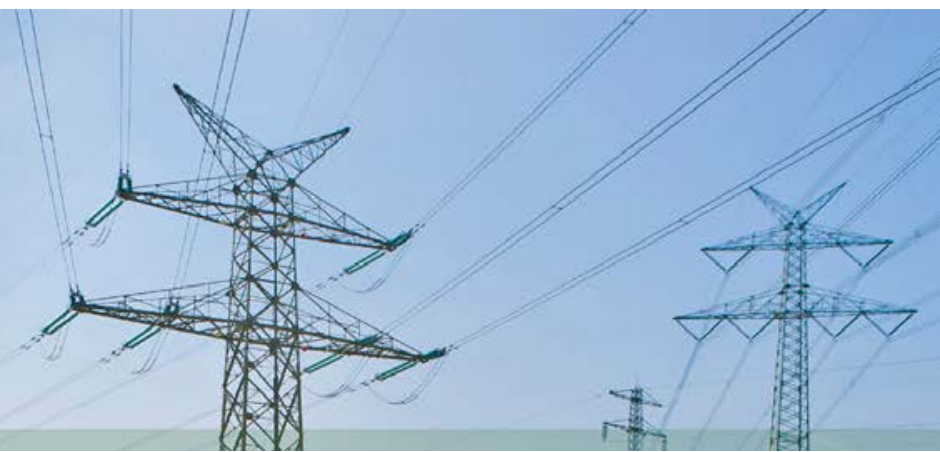

\title{
The Status and Outlook of Distributed Generation Public Policy in Mexico
}

Owen Zinaman, Alexandra Aznar, and Francisco Flores-Espino National Renewable Energy Laboratory

Alejandro Tovar Garza Independent Consultant 


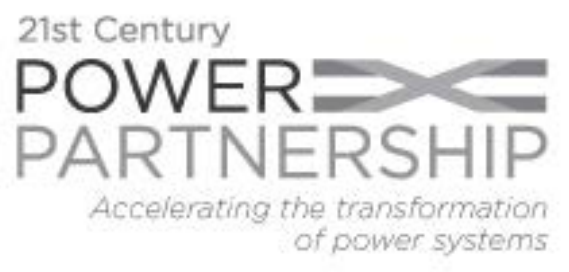

\title{
The Status and Outlook of Distributed Generation Public Policy in Mexico
}

Owen Zinaman, Alexandra Aznar, and Francisco Flores-Espino National Renewable Energy Laboratory

\author{
Alejandro Tovar Garza \\ Independent Consultant
}

\section{Suggested Citation}

Owen Zinaman, Alexandra Aznar, Francisco Flores-Espino, and Alejandro Tovar Garza. 2018, The Status and Outlook of Distributed Generation Public Policy in Mexico. Golden, CO: National Renewable Energy Laboratory. NREL/ TP-6A50-71469.

https://www.nrel.gov/docs/fy18osti/71469.pdf.

NREL is a national laboratory of the U.S. Department of Energy, Office of Energy

Efficiency \& Renewable Energy, operated by the Alliance for Sustainable Energy, LLC.

National Renewable Energy Laboratory 15013 Denver West Parkway Golden, CO 80401

303-275-3000 • www.nrel.gov
Technical Report

NREL/TP-6A50-71469

May 2018

Contract No. DE-AC36-08G028308 


\section{NOTICE}

This report was prepared as an account of work sponsored by an agency of the United States government. Neither the United States government nor any agency thereof, nor any of their employees, makes any warranty, express or implied, or assumes any legal liability or responsibility for the accuracy, completeness, or usefulness of any information, apparatus, product, or process disclosed, or represents that its use would not infringe privately owned rights. Reference herein to any specific commercial product, process, or service by trade name, trademark, manufacturer, or otherwise does not necessarily constitute or imply its endorsement, recommendation, or favoring by the United States government or any agency thereof. The views and opinions of authors expressed herein do not necessarily state or reflect those of the United States government or any agency thereof.

This report is available at no cost from the National Renewable Energy Laboratory (NREL) at www.nrel.gov/publications.

Available electronically at SciTech Connect http:/www.osti.gov/scitech

Available for a processing fee to U.S. Department of Energy and its contractors, in paper, from:

U.S. Department of Energy

Office of Scientific and Technical Information

P.O. Box 62

Oak Ridge, TN 37831-0062

OSTI http://www.osti.gov

Phone: 865.576.8401

Fax: 865.576.5728

Email: reports@osti.gov

Available for sale to the public, in paper, from:

U.S. Department of Commerce

National Technical Information Service

5301 Shawnee Road

Alexandria, VA 22312

NTIS http://www.ntis.gov

Phone: 800.553 .6847 or 703.605 .6000

Fax: 703.605.6900

Email: orders@ntis.gov 


\section{Acknowledgements}

The authors would like to thank Telésforo Trujillo Sotelo (SENER), Edmundo Gil Borja (SENER), Fidel Carrasco Gonzalez (CRE), and Efraín Villanueva Arcos (SENER) for their input and review of this work. We would also like to thank reviewers Jason Coughlin (NREL), Riccardo Bracho (NREL), and Jeffrey Logan (NREL) for their feedback. Lastly, the authors thank Britton Marchese (NREL) and Douglas Gagne (NREL) for their editorial support. Any remaining errors are the responsibility of the authors. 


\section{Acronyms and Abbreviations}

21CPP

ANCE

ANES

ASOLMEX

BNEF

CELS

CeMIE Sol

CENACE

CFE

CONOCER

CONUEE

CRE

DAC

DG

DSIRE

DTI

FATERGED

FIDE

FIRCO

FOTEASE

GEF

GHG

GIZ

GTM

ICM

IFC

INFONAVIT

IREC $21^{\text {st }}$ Century Power Partnership

Asociación de Normalización y Certificación

Asociación de Energía Solar A.C. (Solar Energy Association)

Asociación Mexicana de Energía Fotovoltaica A.C. (Mexican Photovoltaic

Energy Association)

Bloomberg New Energy Finance

Certificados de Energías Limpias (clean energy certificates)

Centro Mexicano de Innovación en Energía Solar (Mexican Center for Solar

Energy Innovation)

Centro Nacional de Control de Energía (National Center for Energy Control)

CFE Distribución (CFE Distribution)

Comité Técnico del Consejo Nacional de Normalización y Certificación de

Competencias Laborales (National Council for Workforce Certification

Technical Committee)

Comisión Nacional para el Uso Eficiente de la Energía (National

Commission for Energy Efficiency)

Comisión Reguladora de Energía (Energy Regulatory Commission)

(Tarifa) Doméstica de Alto Consumo (High consumption rate)

distributed generation

Database of State Incentives for Renewables \& Efficiency

South African Department of Trade and Industry

Financiamiento para Acceder a Tecnologías de Energías Renovables de

Generación Eléctrica Distribuida (Financing to Access Distributed

Renewable Energy Technologies)

Fideicomiso para el Ahorro de Energía Eléctrica (Trust for Energy

Conservation)

Fideicomiso de Riesgo Compartido (Shared-risk Trust)

Fondo para la Transición Energética y el Aprovechamiento (Energy

Transition Fund)

Global Environmental Facility

greenhouse gas

German Technical Cooperation

Greentech Media

Iniciativa Climática de México (Mexican Climate Initiative)

International Finance Corporation

Instituto del Fondo Nacional de la Vivienda para los Trabajadores (Mexican Federal Institute for Worker's Housing)

Interstate Renewable Energy Council 


$\begin{array}{ll}\text { ITC } & \text { Investment Tax Credit } \\ \text { LTE } & \text { Ley de la Transición Energética (Energy Transition Act) } \\ \text { NCS } & \text { National Competence System } \\ \text { NEM } & \text { net energy metering } \\ \text { NMX } & \text { Mexican Norm } \\ \text { NOM } & \text { Official Mexican Norm } \\ \text { NREL } & \text { National Renewable Energy Laboratory } \\ \text { NYSERDA } & \text { New York State Energy Research and Development Authority } \\ \text { PACE } & \text { property-assessed clean energy } \\ \text { PCG } & \text { Partial Credit Guarantee } \\ \text { PETE } & \text { Programa Especial de la Transición Energética (Special Program for the } \\ \text { PPA } & \text { Energy Transition) } \\ \text { PREI } & \text { power purchase agreement } \\ \text { PRODESEN } & \text { Programa de Redes Eléctricas Inteligentes (Smart Grid Program) } \\ \text { Programa de Desarrollo del Sistema Eléctrico Nacional (National Electric } \\ \text { Pystem Development Program) } \\ \text { RECS } & \text { Programa de Fomento de Sistemas Fotovoltaicos (Program for the } \\ \text { REIPPPP } & \text { renewation of Photovoltaic Systems) } \\ \text { RES LEGAL } & \text { Renewable Independent Power Producer Procurement Programme (in South } \\ \text { RGD } & \text { Legal Sources on Renewable Energy } \\ \text { RMI } & \text { Red general de distribución (General distribution networks) } \\ \text { RPS } & \text { Rocky Mountain Institute } \\ & \text { renewable portfolio standards } \\ \text { SAGARPA } & \text { Secretaría de Agricultura, Ganadería, Desarrollo Rural, Pesca y } \\ & \text { Alimentación (Secretariat of Agriculture, Livestock, Rural Development, } \\ \text { SE } & \text { Fisheries and Food of Mexico) } \\ \text { SEIA } & \text { Secretaría de Economía (Secretariat of Economy) } \\ \text { SENER } & \text { Solar Energy Industries Association } \\ \text { SEP } & \text { Secretaría de Energía de México (Mexico’s Ministry of Energy) } \\ \text { SME } & \text { Secretaría de Educación Pública (Public Education Ministry) } \\ \text { SREC } & \text { small- and medium-scale enterprises } \\ \text { TOU } & \text { Solar Renewable Energy Credit } \\ & \text { time-of-use rate } \\ & \end{array}$




\section{Executive Summary}

Recent clean energy reforms are rapidly transforming Mexico's energy landscape as Mexico pursues its goals of generating 35\% of its electricity from clean energy by 2024 and reducing greenhouse gas emissions by $22 \%$ by 2030 . As part of these goals, clean distributed generation is slated to play a meaningful role in Mexico's energy landscape and is a key priority for policymakers. This report provides insight into the dynamic distributed generation landscape in Mexico and is intended to guide discussions on distributed generation policy options.

As of June 30, 2017, distributed generation deployment in Mexico reached a cumulative 304 MW and was comprised mostly of PV systems (CRE, 2017). However, a gap remains in reaching Mexico's near-term goal of 527 MW of clean distributed generation deployment by 2018, which has sparked multiple public policy discussions in Mexico. To address this gap, new distributed generation public policies will be published by the Government of Mexico and may need to evolve to meet consumer demand and support integration of increasing levels of distributed generation, particularly from renewable sources. Ultimately, Mexico intends to develop a comprehensive distributed generation policy that promotes consumer choice, creates a stable environment for investment, leverages market-based signals, and uses public funding efficiently.

To support Mexico's public policy development, this report summarizes the current status of distributed generation markets, laws, and regulations in Mexico, providing readers with a common foundation of knowledge. This includes an explanation of core distributed generation issues, opportunities, and prospects for Mexico. Distributed generation policies are organized into ten categories and discuss how each element is currently addressed in Mexico, as well as any existing barriers. In order to understand how public policy has been used to promote the deployment of distributed generation internationally, NREL reviewed DG policies and grouped them in the following categories:

- Establish a sufficient compensation rate for distributed generation owners

- Establish targeted financial incentives

- Expand access to financing for distributed generation options

- Expand customer access to distributed generation options

- Encourage the maturation and quality of suppliers, materials, and labor

- Establish best-practice interconnection processes

- Promote locally manufactured content

- Promote public awareness of distributed generation options

- Encourage the reduction of electricity tariff subsidy payments

- Establish a clearly defined role of the distribution utility for distributed generation 


\section{Table of Contents}

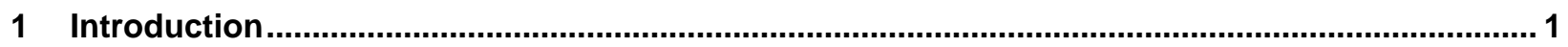

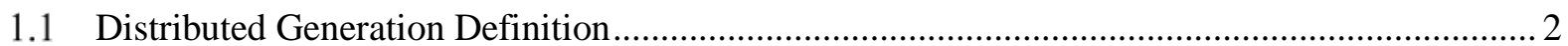

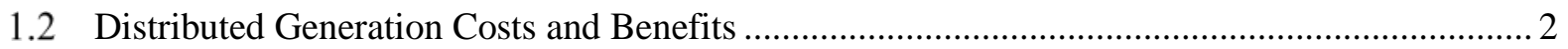

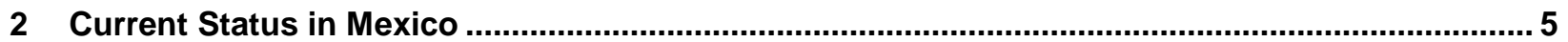

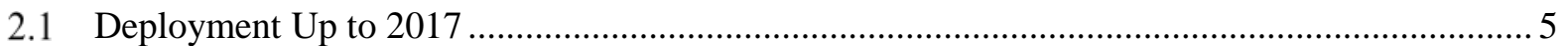

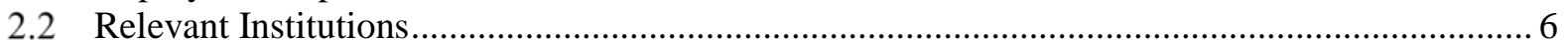

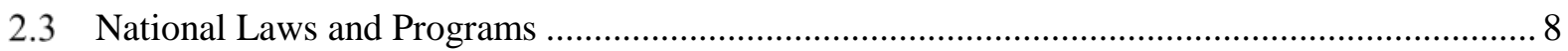

3 The Path toward a Comprehensive Distributed Generation Public Policy in Mexico ................. 12

3.1 Establish a Sufficient Compensation Rate for Distributed Generation Owners......................... 13

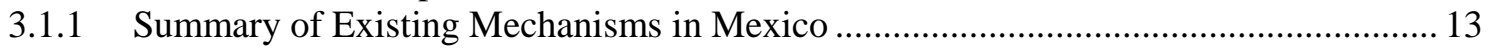

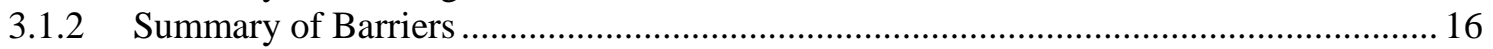

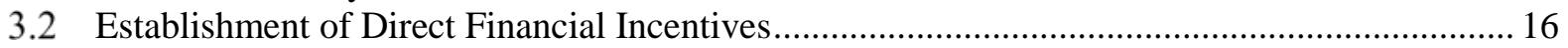

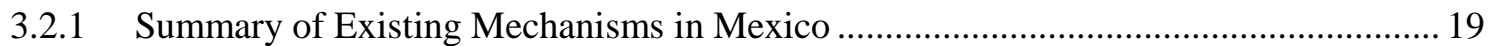

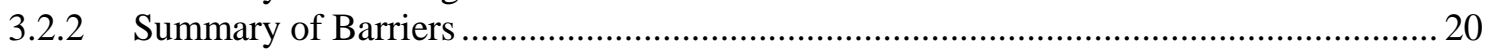

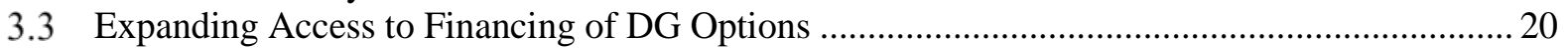

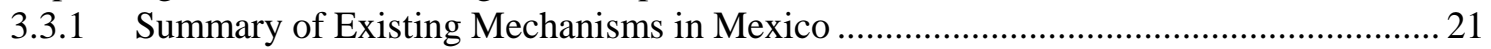

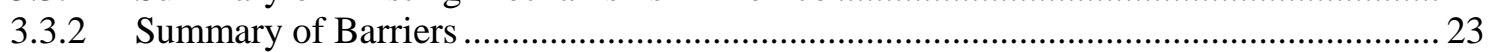

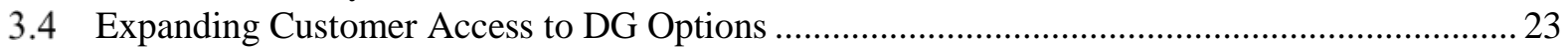

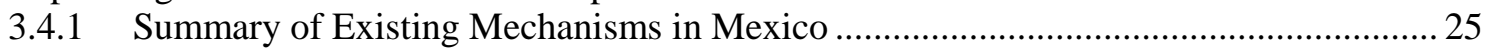

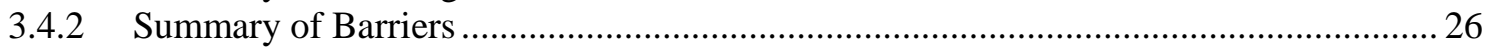

3.5 Encourage the Maturation and Quality of Suppliers, Materials and Labors ............................. 26

3.5.1 Summary of Existing Mechanisms in Mexico ........................................................ 26

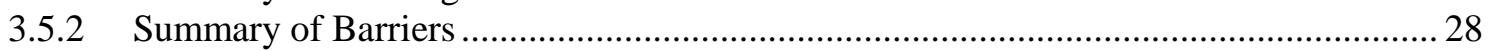

3.6 Establishment of Best Practice Interconnection Procedures .................................................. 28

3.6.1 Summary of Existing Mechanisms in Mexico …........................................................... 30

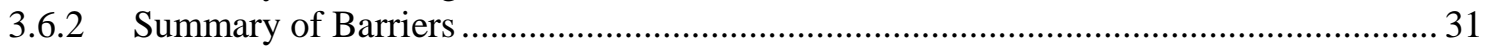

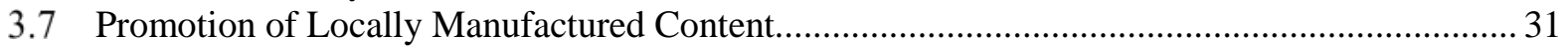

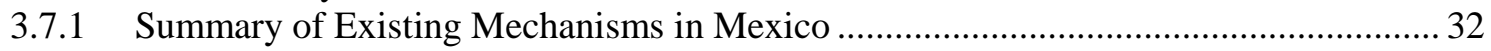

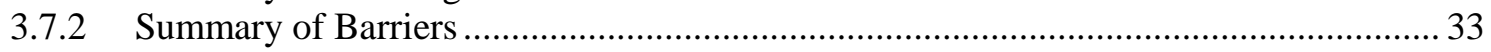

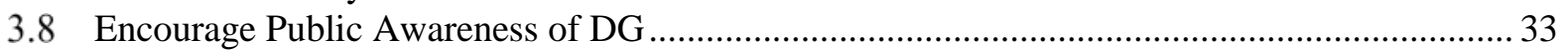

3.8.1 Summary of Existing Activities in Mexico ............................................................. 34

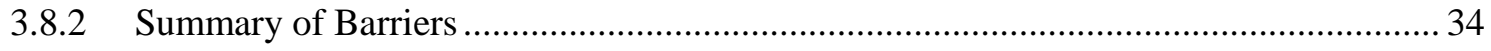

3.9 Encourage the Reduction of Electricity Tariff Subsidy Payments ............................................ 34

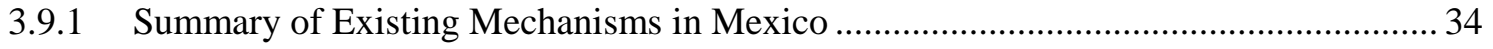

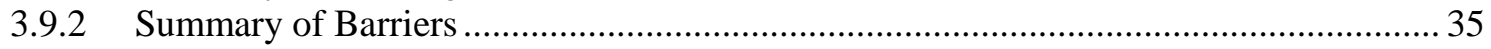

3.10 Establish Clearly Defined Role of CFE for DG …................................................................ 35

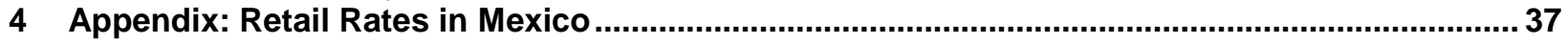

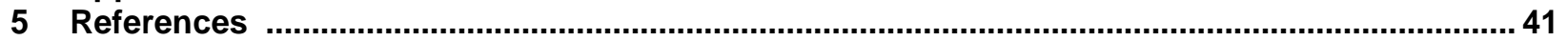




\section{List of Figures}

Figure 1. DG cost and benefit categories from different perspectives..................................................... 3

Figure 2. Accumulated installed small- and mid-scale capacity and number of contracts in Mexico by

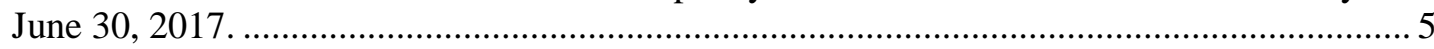

Figure 3. Accumulated installed small- and mid-scale capacity and number of contracts in Mexico by

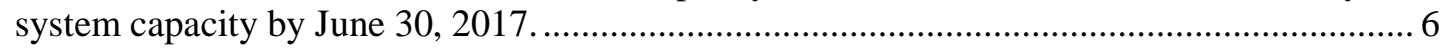

Figure 4. Alignment of national laws, strategy and programs related to DG. ........................................ 11

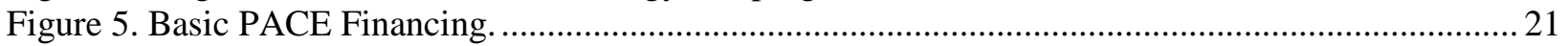

Figure 6. Typical third-party developer community solar model. ..................................................... 24

Figure 7. States with Meter Aggregation Policies. ................................................................................ 25

Figure 8. Installed manufacturing capacity of PV panels in Mexico (MW) Summary of Barriers ............ 33

Figure 9. Residential tariff inclining block structure, Summer 2015...................................................... 38

\section{List of Tables}

Table 1. Distributed generation costs and benefit factors and perspectives............................................. 3

Table 2. Summary of DG compensation mechanisms in Mexico............................................................ 15

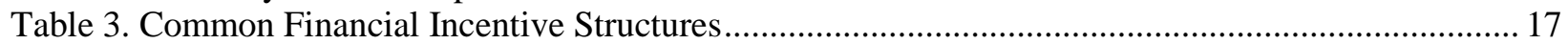

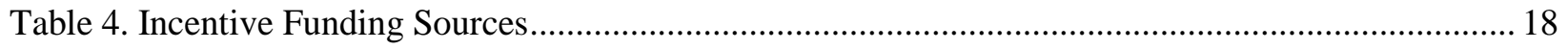

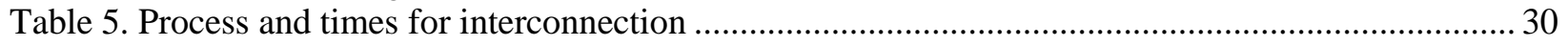

Table 6. Retail rates in Mexico according to the voltage level of the network that serves them................. 37

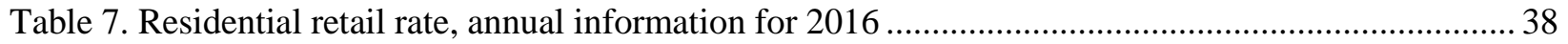

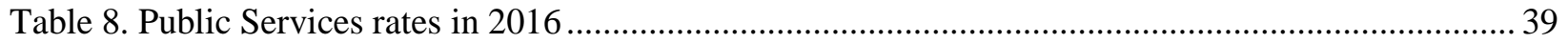

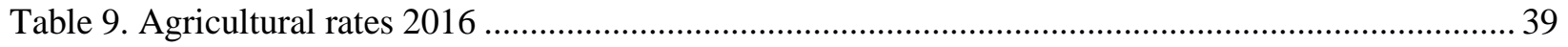

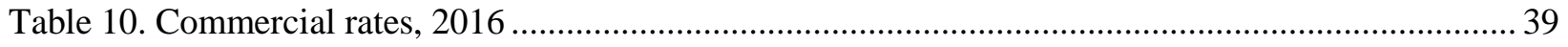

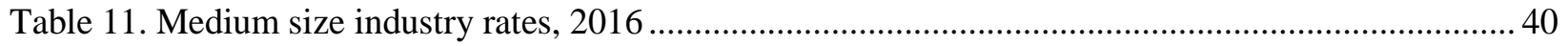




\section{Introduction}

Mexico is rapidly and comprehensively reforming its energy system, especially to provide cleaner, more affordable power and distributed generation (DG) development is a key priority for the country’s policymakers. Current DG policies have fostered growth but need to be modernized to serve current needs and accommodate higher penetration levels. In this report, the authors present a snapshot of Mexico’s dynamic DG landscape. The purpose of this report is to:

1. Provide detailed background information on the status of DG in Mexico, including market information and recent legal and regulatory developments; and

2. Explain core issues, opportunities, and prospects for DG in Mexico.

This report is intended to be a starting point that provides DG stakeholders in Mexico with the background information, facts, and various perspectives needed to inspire an informed discussion about DG policy reform.

This report builds upon previous work by the government of Mexico and local and international technical partners. ${ }^{1}$ The $21^{\text {st }}$ Century Power Partnership (21CPP) ${ }^{2}$ technical report titled 'Designing Distributed Generation in Mexico’ outlines various foundational elements of DG regulation and public policy for Mexico, and presents international experiences, objectives, and action items for the government of Mexico to consider (Linvill and Brutkoski 2017). The SENER analysis titled 'Initial Analysis about the Benefits from Clean Distributed Energy and Energy Efficiency in Mexico'3 ${ }^{3}$ constitutes the first effort by the Mexican government to quantify the benefits of DG - and energy efficiency — for the federal government, the environment, and society (SENER 2017a). SENER's analysis helped to quantify the potential value of pursuing a strong DG policy in Mexico and indicated that public policy could help bridge the gap of costs and benefits between consumers and the government.

The material in this report was first presented at the July 6, 2017 public stakeholder meeting hosted by Mexico’s Ministry of Energy (Secretaría de Energía de México [SENER]) titled "Mexico’s Distributed Generation Public Policy Workshop" ${ }^{4}$ in which the direction of DG public policy in Mexico was discussed.

\footnotetext{
${ }^{1}$ This includes the Deutsche Gesellschaft für Internationale Zusammenarbeit (GIZ), the U.S. Agency for International Development (USAID), the 21st Century Power Partnership (21CPP), Universidad Nacional Autónoma de México (UNAM), Centro de Investigación y Docencia Económicas (CIDE), y Iniciativa Climática de México (ICM).

2 The 21CPP is a multilateral initiative of the Clean Energy Ministerial that the Government of Mexico co-leads. The U.S. National Renewable Energy Laboratory is the Operating Agent for the 21CPP; NREL's activities to support the Government of Mexico are funded by the Children's Investment Fund Foundation.

${ }^{3}$ Primer análisis sobre los beneficios de la generación limpia distribuída y la eficiencia energética en México (SENER 2017a).

${ }^{4}$ Taller para la Elaboración de Políticas Públicas en Generación Distribuida en México
} 


\subsection{Distributed Generation Definition}

Although there is not a single shared definition for distributed generation among the different jurisdictions worldwide, the term is generally used to refer to power generation located near the point of consumption, as opposed to centralized generation, which is typically located outside of the distribution network. Frequently, distributed generators are located on the consumption side of the customer's meter, and the electricity generated by a DG system can be either consumed on-site or injected into the local grid.

The government of Mexico defines distributed generation as energy produced by systems that have a nameplate generating capacity below $500 \mathrm{~kW}$ (which is the threshold at which generators require a generation permit from the Energy Regulatory Commission ${ }^{5}$ ), and below the expected demand from all the loads interconnected to the same distribution circuit. ${ }^{6,7}$

\subsection{Distributed Generation Costs and Benefits}

There are various costs and benefits of DG for the utility, DG customers, other customers, and society. Costs and benefits of DG are also realized at different points in time (Woolf et al. 2016). Whether a factor is deemed a cost or a benefit depends on the stakeholder perspective.

Although the specific quantification of DG costs and benefits depends on both the context and the analytical methods employed, there are some generally recognized categories of DG costs and benefits that include energy, capacity, grid support services, financial risks, security risks, environmental risks, and social benefits (Figure 1) (RMI 2013). The net value (i.e. benefitscosts) for each category may be positive or negative depending on the scale of benefits and costs and the stakeholder perspective. Although DG cost-benefit analyses to date share some commonalities, there is currently no standardized methodology for assessing costs and benefits.

\footnotetext{
${ }^{5}$ Electricity Industry Act, Article 16

${ }^{6}$ Electricity Industry Act, Article 3, XXIII

${ }^{7}$ Interconnection Manual for Generation Plants Under 0.5 MW of Capacity
} 


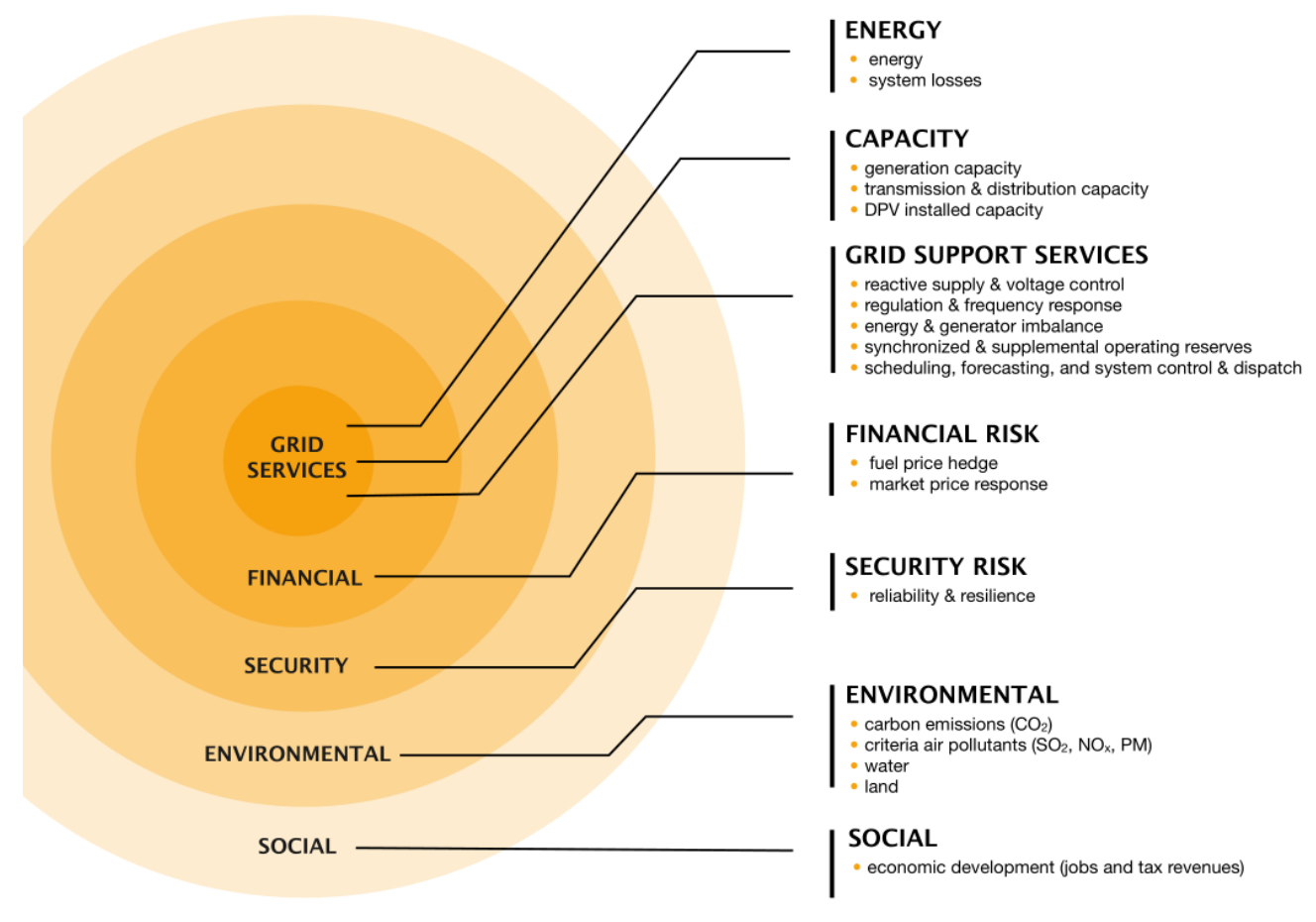

Image from RMI (2013)

Figure 1. DG cost and benefit categories from different perspectives.

Costs and benefits are categorized differently by stakeholders, as shown in Table 1 below.

Table 1. Distributed generation costs and benefit factors and perspectives.

\begin{tabular}{|c|c|}
\hline Stakeholder perspective & Factors affecting value \\
\hline DG customer & $\begin{array}{l}\text { Benefits: Reduced utility bill, additional incentives, tax credits, consumer } \\
\text { empowerment } \\
\text { Costs: DG system cost }\end{array}$ \\
\hline $\begin{array}{l}\text { Other customers (e. g. } \\
\text { ratepayers) }\end{array}$ & $\begin{array}{l}\text { Benefits: Reduction in transmission, distribution, and generation capacity costs, } \\
\text { energy costs, and grid support services }{ }^{8} \\
\text { Costs: Administrative costs, rebates/incentives, decreased utility revenue that is } \\
\text { offset by increased rates }\end{array}$ \\
\hline Utility & $\begin{array}{l}\text { Benefits: Reduction in transmission, distribution, and generation capacity costs, } \\
\text { energy costs, and grid support services } \\
\text { Costs: administrative costs, rebates/ incentives, decreased revenue, integration and } \\
\text { interconnection costs }\end{array}$ \\
\hline Society & $\begin{array}{l}\text { Sum of the benefits and costs to all stakeholder + additional societal and } \\
\text { environmental benefits or costs that accrue to society at large rather than any } \\
\text { individual stakeholder. }\end{array}$ \\
\hline
\end{tabular}

Adapted from Rocky Mountain Institute, Review of Solar PV Benefit and Cost Studies 2013

${ }^{8}$ These are potential reductions. Costs may rise with increasing penetrations of distributed solar, but the threshold at which this may occur depends on many factors. 
Although Mexico has begun the process of identifying context-specific costs and benefits of DG for different stakeholders, there is room for additional assessments. In 2017, SENER quantified the benefits of DG (specifically, distributed solar) for the federal government, the environment, and society (SENER 2017a). This analysis indicated that a contribution of distributed solar equivalent to $1 \%$ of the national installed capacity, results in savings for the government of Mexico equal to 1,500M pesos, 680 million liters of avoided water use, and 1.3 million tons of avoided $\mathrm{CO}_{2}$ emissions. While this is an important initial study, a further examination of the full costs and benefits of DG that quantifies the full value of DG for various stakeholders in Mexico is needed for a more comprehensive analysis.

Why is understanding the costs and benefits (i.e. DG value) so important? The policies selected and implemented by Mexico will be more sustainable if they are fair to adopters of DG, fair to all customers including those who do not adopt DG, fair to utility investors, fair to third party participants in the marketplace, and beneficial to society as a whole. Broadly speaking, fair policies that are in the public interest must consider the DG value proposition from each of these perspectives. Before a portfolio of policies can be developed and tailored specifically for Mexico, the value proposition presented by DG must first be considered. Choosing and designing effective DG policies for Mexico would be enhanced by implementation of a valuation exercise that seeks to identify the full and fair value of DG technologies in Mexico from various perspectives. 


\section{Current Status in Mexico}

Distributed generation development in Mexico is evolving with assistance from new legislation, programs, and government and industry players. This section identifies DG stakeholders in Mexico, existing national laws and programs that address DG, and DG deployment to date.

\subsection{Deployment Up to 2017}

The cumulative DG deployment in Mexico through June 30, 2017 was 304 MW, and was composed almost entirely (98\%) of solar PV systems (CRE 2017a). Figure 2 shows cumulative DG installed capacity from 2007 to 2017.

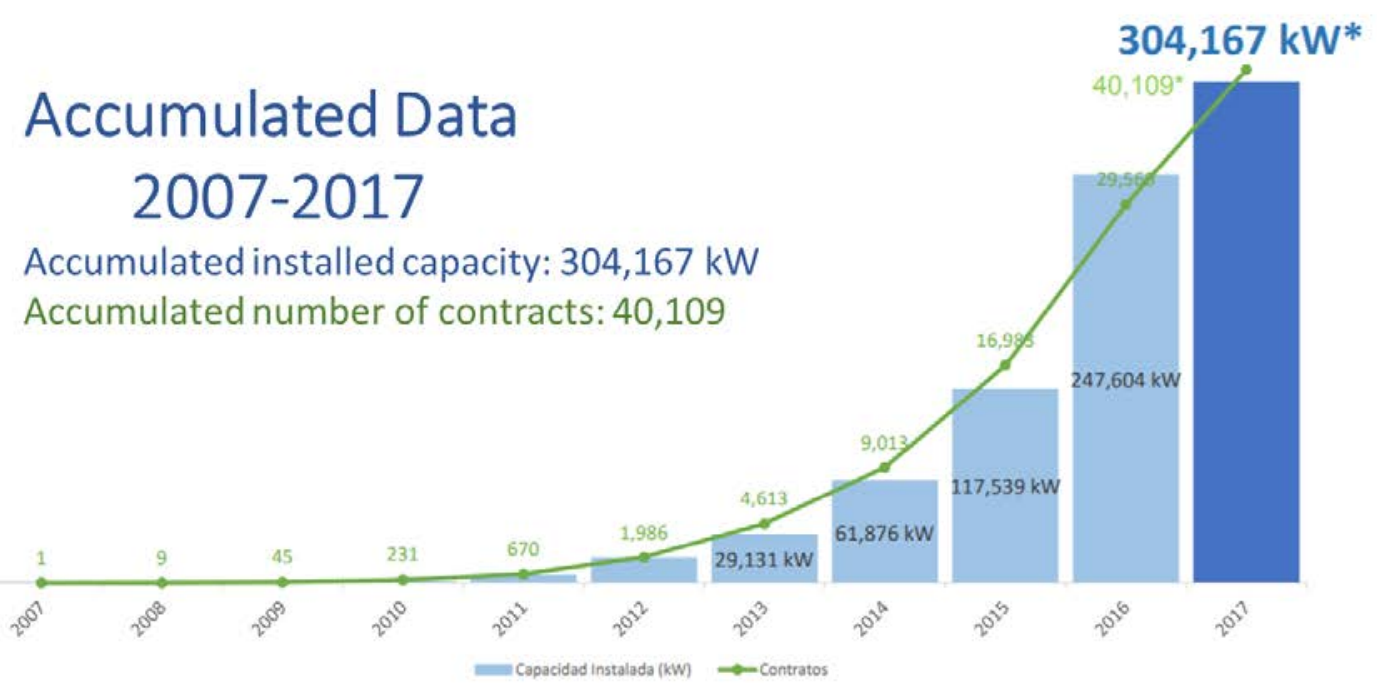

Image from Energy Regulatory Commission - Comisión Reguladora de Energía (CRE) (2017a)

Figure 2. Accumulated installed small- and mid-scale capacity and number of contracts in Mexico by June 30, 2017. 
Figure 3 shows the accumulated DG installed capacity and number of contracts by system size.

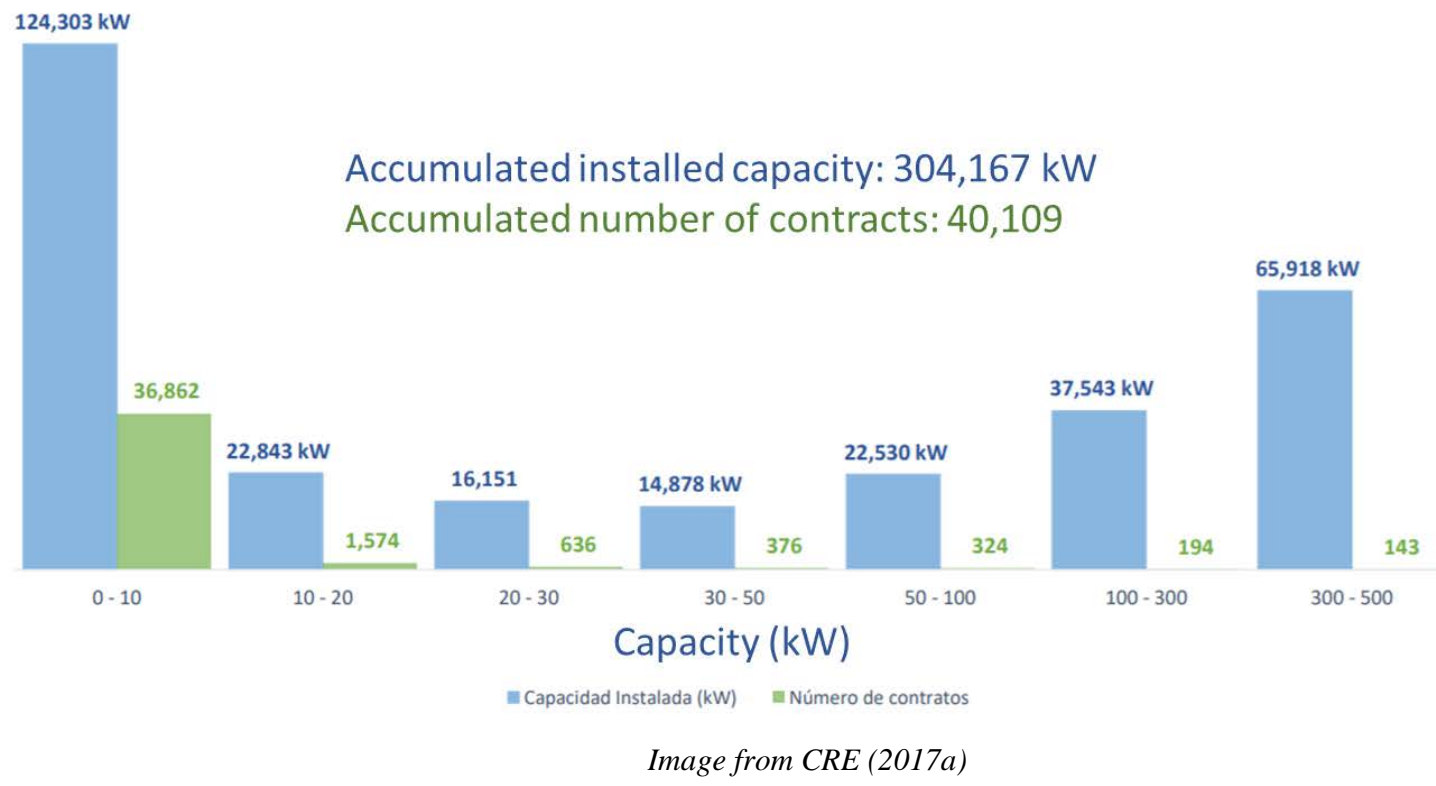

Figure 3. Accumulated installed small- and mid-scale capacity and number of contracts in Mexico by system capacity by June 30, 2017.

\subsection{Relevant Institutions}

The numerous stakeholders in Mexico involved in DG activities include consumers, industry, academia, and the government. The following list of mainly governmental agencies with their attributions and responsibilities, has been identified as primary entities by Mexican legislation.

Ministry of Energy - Secretaría de Energía (SENER). SENER is a government agency in charge of developing energy policy. DG-related attributions and responsibilities include:

- Determining public policy for DG

- Promoting loans and other forms of financing mechanisms to support DG

- Developing interconnection manuals for DG systems

- Submitting proposals to the Finance Ministry to implement mechanisms and tax or financial incentives that support DG deployment.

Energy Regulatory Commission - Comisión Reguladora de Energía (CRE). CRE is the government's energy regulatory body, ensuring the efficient and fair development and exploitation of energy technologies and fuels. DG-related attributions and responsibilities include:

- Developing DG regulation and compensation methodology

- Developing standard contracts for DG interconnection and compensation (see text box below). 
- Approving CENACE's technical specifications for DG system interconnection (see CENACE's entry below)

- Allocating, monitoring, tracking, and verifying Clean Energy Certificates (CELs). ${ }^{9}$

Standard Contracts: Standard contracts in Mexico are a regulatory instrument defined and approved by the Energy Regulatory Commission. Interconnection contracts are between the distributor and the customer, whereas compensation contracts are between the supplier and the customer. The contracts outline necessary administrative information about the customer, the obligations of all parties involved, contract validity and expiration dates, and other relevant information such as the interconnection voltage or the compensation mechanism chosen by the customer.

National Center for Energy Control - Centro Nacional de Control de Energía (CENACE). CENACE is Mexico's independent system operator in charge of the national electricity network. DG-related attributions and responsibilities include:

- Defining technical specifications and infrastructure requirements for DG system interconnection

- Performing interconnection studies for power plant (>500 kW) interconnection.

Electricity Distribution Company ${ }^{10}$ - CFE Distribution (CFE Distribución). CFE Distribución is responsible for maintaining, operating, and planning distribution networks. DGrelated responsibilities include:

- Including reinforcement and expansion projects that incorporate DG integration in its yearly modernization and expansion plan

- Developing studies for DG interconnection

- Interconnecting DG systems to the electric grid once all requirements are fulfilled

- Signing the interconnection contract with the applicant.

Electricity Supplier ${ }^{11}$. CFE Basic Supplier (CFE Suministro Básico) will be the default electricity supplier. Consumers with peak demands of $1 \mathrm{MW}$ or more can select other suppliers, such as power marketers, or buy directly from the wholesale market. DG-related responsibilities include:

- Receiving and managing all interconnection requests for DG

- Managing and compensating DG exports to the grid

- Signing the compensation contract with the applicant.

\footnotetext{
${ }^{9}$ Clean Energy Certificates, or Certificados de Energías Limpias (CELs), are tradeable certificates used to track and verify clean energy goal compliance. Each CEL is equivalent to 1 MWh of clean energy.

${ }^{10}$ The distribution company (the distributor) owns and manages the general distribution network, whereas the electricity supplier (the supplier) is the utility that sells the electricity to the end users.

${ }^{11} \mathrm{CFE}$ is the default electricity supplier. Only customers with a peak load greater than $1 \mathrm{MW}$ can choose a different supplier.
} 
Shared SENER, CRE, CENACE and CONUEE ${ }^{12}$ responsibilities include:

- Establishing and adjusting hardware, performance, and installation requirements for clean DG systems

- Establishing certification standards for clean DG installers

- Promoting domestic capacity building

- Certifying clean DG installation companies, professionals and technicians.

Trust for Energy Conservation - Fideicomiso para el Ahorro de Energía Eléctrica (FIDE) is a private trust with the objective of promoting energy savings measures in industrial, commercial, residential, and municipal electricity consumers. DG-related responsibilities include:

- Certifying and providing financing for technologies that help reduce energy consumption

- Certifying qualified project developers

- Validating and supervising projects funded by FIDE

- Training project developers in the correct use of FIDE-certified technologies.

\subsection{National Laws and Programs}

The government of Mexico has the goal of transitioning to cleaner and more diversified sources of energy to increase energy security, minimize the volatile effects from fossil fuel dependence, and minimize environmental impacts (SENER 2017b). With this goal, the government has issued several laws, strategies, and programs to support the development and integration of renewable energy generally, and DG in particular. This section summarizes the ways in which each law or program promotes DG adoption.

\section{The Electricity Industry Act - Ley de la Industria Eléctrica (LIE) (DOF 2014), Enacted in 2014}

After the constitutional modifications that enabled Mexico's energy reforms, the Electricity Industry Act was one of the foundational pieces of legislation that codified the reforms into law. The act does the following:

- Assigns the responsibility of crafting DG policy to SENER

- Requires SENER to produce the PRODESEN (see below), which must include plans for the expansion and modernization of the distribution network

- Requires the relevant government agencies (see Section 2.2) to issue DG norms, regulations, and standard contracts

- Guarantees open and nondiscriminatory access to transmission and distribution networks

- Requires electricity market rules to define criteria for recognizing DG capacity

\footnotetext{
${ }^{12}$ National Commission for Energy Efficiency - Comisión Nacional para el Uso Eficiente de la Energía
} 
- Permits third-party ownership of DG

- Assigns responsibilities to SENER, CRE, CENACE and CONUEE to establish technical and normative specification to integrate DG in the general distribution network

\section{Energy Transition Act - Ley de la Transición Energética (LTE) (DOF 2015), Enacted in December 2015}

The Energy Transition Act, which was the last of the energy reform's foundational laws, modernized existing clean energy legislation and goals, including the country's clean energy standard of $35 \%$ by 2024 . The act does the following:

- Incorporates the definition of clean distributed generation

- Requires SENER to submit proposals to support mechanisms, and tax or financial incentives to the Finance Ministry (Secretaría de Hacienda y Crédito Público), with the goal of promoting economically and technically viable measures for the integration of DG

- Requires SENER to promote credit and financing availability for clean DG

- Requires a study about economic and GHG reduction benefits from residential DG deployment

- Requires the creation of the Smart Grid Program (PREI ${ }^{13}$ )

National Electric System Development Program - Programa de Desarrollo del Sistema Eléctrico Nacional 2017-2030 (PRODESEN) (SENER 2017c), Published Annually by SENER

The PRODESEN documents the government planning process regarding electrical generation, transmission, and distribution. PRODOSEN does the following:

- Considers grid expansion and upgrades to promote the deployment of clean DG, particularly in zones where the benefits would be the highest

- Evaluates distribution network expansion and modernization requirements for DG interconnection

- Simplifies interconnection processes and requirements

- Eliminates DG development barriers.

Smart Grid Program - Programa de Redes Eléctricas Inteligentes (PREI) (SENER 2016b), Published in May 2016 ${ }^{14}$

The PREI is a national smart grid roadmap aimed at promoting and coordinating smart grid technology deployment. The PREI:

\footnotetext{
${ }^{13}$ The Programa de Redes Inteligentes (PREI) has been previously known by the acronyms PRODERI and PRERI.

${ }^{14}$ There was a PREI update issued in 2017.
} 
- Has goals that include identifying, evaluating, designing, establishing and implementing strategies, actions, and projects related to smart grids, including developing and integrating DG projects.

- Outlines policies to deploy smart grids that include the expansion and modernization of the national electric system, using smart grid technologies that enable the efficient integration of renewable energy and DG.

Transition Strategy to Promote Cleaner Technologies and Fuels - Estrategia de Transición para Promover el Uso de Tecnologías y Combustibles más Limpios (SENER/CONUEE 2016), Published in October 2016

This document outlines the overarching 30-year and 15-year strategies to increase clean energy deployment and energy efficiency and reduce pollutant and greenhouse gas emissions. DGrelated goals and activities outlined in the document include:

- Adopting international performance and manufacturing standards for DG

- Measuring DG costs and benefits and promoting measurement and verification

- Setting mid-and long -term goals for DG deployment

- Strengthening the legal rights of DG owners

- Developing domestic technical capabilities and human resources

- Establishing financing mechanisms for technologies needed to integrate DG and smart grids

- Supporting DG pilot programs

- Strengthening research and academic programs and projects.

\section{Special Program for the Energy Transition - Programa Especial de la Transición} Energética 2017-2018 (PETE) (SENER 2017b), Published in April 2017

The PETE is a policy-planning initiative to coordinate the government's strategy to promote clean energy deployment. Regarding DG, it outlines strategies to expand and modernize DG infrastructure and to increase the deployment of DG and energy storage.

The PETE includes information about the current status of clean energy (e.g., installed and projected capacity), DG objectives—such as improving DG policy and installed capacity goalsand performance indicators.

The alignment of the main policy instruments is presented in Figure 4. 


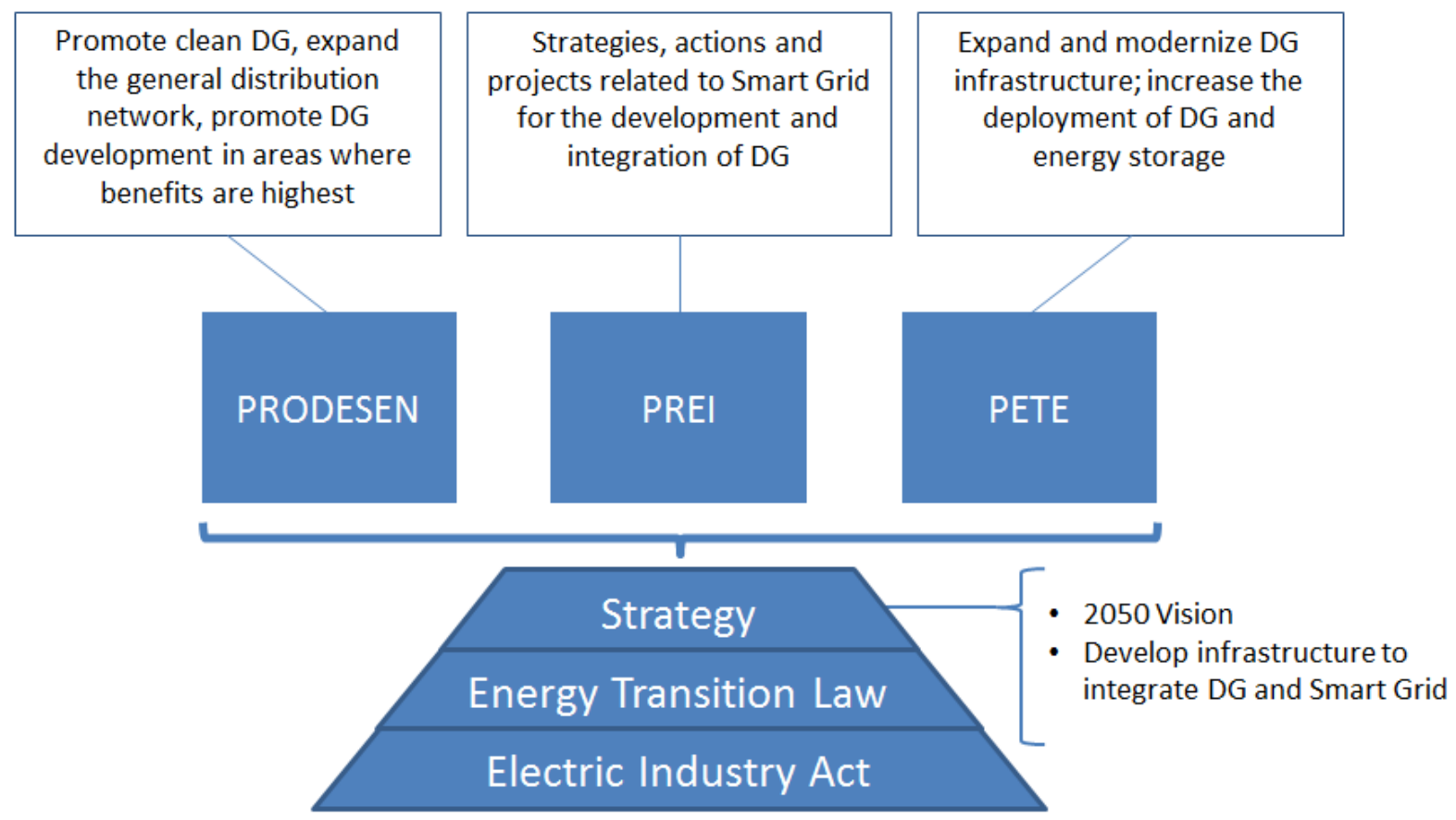

Energy Transition Law and Electric Industry Act Principles:

- Incentives and financing

- Open access to the grid

- Enable energy trading
- Standardization, training and certification

- Enable installations and interconnections

Image adapted from Tovar (2017)

Figure 4. Alignment of national laws, strategy and programs related to DG. 


\section{The Path toward a Comprehensive Distributed Generation Public Policy in Mexico}

Promoting customer knowledge and adoption of distributed generation and energy efficiency is a priority for the Mexican government (SENER 2017a). The government energy reforms prioritize DG promotion through market-based signals, as opposed to direct subsidies. The government of Mexico intends to establish a comprehensive distributed generation public policy strategy with substantial stakeholder input. In principle, this public policy strategy will strive to:

- Maintain a stable and predictable environment for investment in DG resources

- Promote energy democratization and consumer choice in energy decisions, established by the Energy Transition Law

- $\quad$ Promote the efficient use of public funding to support DG deployment, where appropriate, supported by the identification of costs and benefits

- Meet the government of Mexico’s near-term goal of $527 \mathrm{MW}$ of clean distributed generation deployment by 2018.

In order to understand how public policy has been used to promote DG deployment internationally, NREL reviewed DG policies and grouped them in the following categories:

1. Establish a sufficient compensation rate for distributed generation owners

2. Establish targeted financial incentives

3. Expand access to financing for DG options

4. Expand customer access to DG options

5. Encourage the maturation and quality of suppliers, materials, and labor

6. Establish interconnection process best practices

7. Promote locally manufactured content

8. Encourage public awareness of DG options

9. Encourage the reduction of electricity tariff subsidy payments

10. Establish clearly defined role of CFE for DG.

The following section describes each of these ten DG categories and examines if and how each element is currently addressed in Mexico, and identifies any existing barriers. 


\subsection{Establish a Sufficient Compensation Rate for Distributed Generation Owners}

A DG compensation rate-including grants and other incentives—-that results in a payback period or return on investment that utility customers find acceptable is central to promoting and sustaining the adoption of DG systems in any jurisdiction. However, costs borne by other stakeholders - such as customers who do not own a DG system, the utility, and society at largemust be accounted for. Regulators can select from a number of existing cost tests to balance costs and benefits from different stakeholder perspectives (Linvill \& Brutkoski 2017).

While distributed generation can provide many benefits—-such as reduced emissions (in the case of clean DG) and decreased utility system costs-in some circumstances DG may result in increased bills for non-solar customers (i.e., cost shifting), or the loss of value for utility shareholders (Satchwell et al. 2014). More generally, distributed solar can cause revenues (and subsequently rates) to increase or decrease due to fluctuating electricity sales levels, utility costs, or both. When evaluating costs imposed on customers who do not own DG, the utility, and society, it is important to analyze both long-term and short-term rate impacts to understand costs and benefits that are not realized for several months or years (Woolf et al. 2016).

The information generated by completing a valuation exercise can help in the design of compensation mechanisms and rate designs that do not discriminate against any stakeholder particularly. Such a valuation exercise would need to look across various rate classes and deployment scenarios, and use standard regulatory cost-effectiveness tests such as the Utility Cost Test, Participant Cost Test, and the Societal Cost Test (Linvill and Brutkoski 2017).

The compensation mechanism is the metering and billing arrangement that defines how consumption and generation are measured and billed. While terminology can vary, there are conceptually three types of compensation mechanisms: net energy metering; buy all, sell all; and net billing. Two important values used to calculate the compensation that DG owners receive are the exported energy sell rate and the retail electricity rate.

The exported energy sell rate is the rate paid to customers for selling electricity from their DG system to the utility grid. This quantity is applied to net excess generation for net energy metering, gross DG production for a feed-in tariff, and real-time grid injections for net billing. Sell rates can be fixed for the duration of the contract, calculated sporadically (e.g., annually), or can vary dynamically (e.g., based on locational marginal prices).

The customer's electricity rate is important in cases in which the compensation mechanism allows for the customer to self-consume the electricity that their DG system produces and, therefore, offset their energy consumption. In this case retail electricity rates determine the savings for the customer and influence the DG system's payback period.

\subsubsection{Summary of Existing Mechanisms in Mexico}

Prior to March 2017, Mexico only offered net metering. Three updated DG compensation schemes were published by CRE on March 7, 2017, in the General Administrative Dispositions for Distributed Generation: net energy metering, net billing, and a buy all/sell all (i.e. total sell) (CRE 2017b). Some key points from the regulation are outlined below. 
- $\quad$ Three different compensation schemes are established (Table 2):

o Net Energy Metering: Energy fed into the grid offsets energy consumption from the grid. Net excess generation at the end of the billing cycle (one or two months depending on customer class) is credited to customer's next bill; excess credits in $\mathrm{kWh}$ not used within 12 months of generation are paid to the generator at the average Local Marginal Price of the month when the energy was generated.

o Net Billing: Energy fed into the grid is monetized in real-time at the hourly Local Marginal Price. The credit (in Mexican pesos) can offset the consumption bill.

o Total Sell: Gross DG production is fed into the grid and paid at the hourly Local Marginal Price. This scheme works for DG systems with no on-site consumption.

- The distribution company must include in its yearly modernization and expansion plan, reinforcement and expansion projects to enable DG integration to the grid.

- Ownership of the DG system is not limited to on-site consumers. A third party can own the DG installation and sell energy or lease the system directly to the on-site consumer.

- DG exported to the grid must be compensated by the electricity supplier, which is CFE Distribución by default. Consumers with peak loads above 1 MW can choose alternative suppliers or buy from the wholesale market.

- DG owners who signed contracts prior to the publication of the new regulation can keep their contracts and physical installations under the previous terms or can decide to migrate to the new regulation.

- $\quad$ Storage systems are not considered as additional generation capacity for permitting purposes, as long as the combined energy fed into the grid does not exceed the contracted generation capacity.

- The interconnection process for DG has no cost for the applicant, regardless of the customer class (residential, commercial or industrial). 
Table 2. Summary of DG compensation mechanisms in Mexico

\begin{tabular}{|c|c|c|c|}
\hline \multirow{2}{*}{\begin{tabular}{|l|} 
Implementing Sector: \\
Compensation \\
mechanism:
\end{tabular}} & \multicolumn{3}{|c|}{ Federal (Nationwide) } \\
\hline & Net Metering & Net Billing & Total Sell \\
\hline Eligible technologies: & \multicolumn{3}{|c|}{$\begin{array}{l}\text { All } \\
\text { Clean energy technologies may receive Clean Energy Certificates }\end{array}$} \\
\hline $\begin{array}{l}\text { Applicable customer } \\
\text { classes: }\end{array}$ & \multicolumn{3}{|c|}{ All } \\
\hline $\begin{array}{l}\text { System capacity } \\
\text { limit: }\end{array}$ & \multicolumn{3}{|c|}{$\begin{array}{l}\text { Up to } 50 \mathrm{~kW} \text { in low voltage networks; } \\
\text { Up to } 500 \mathrm{~kW} \text { in medium voltage }\end{array}$} \\
\hline $\begin{array}{l}\text { Aggregate capacity } \\
\text { limit: }\end{array}$ & \multicolumn{3}{|c|}{$\begin{array}{l}\text { None } \\
\begin{array}{l}\text { Regulation will be reviewed in } 2018 \text { and/or once the installed capacity of DG } \\
\text { represents } 5 \% \text { of the total installed capacity in Mexico }\end{array}\end{array}$} \\
\hline $\begin{array}{l}\text { Net Excess } \\
\text { generation/sell rate: }\end{array}$ & $\begin{array}{l}\text { Credited to customer's next bill at } \\
\text { the contracted retail rate; excess } \\
\text { credits not used within } 12 \text { months } \\
\text { of generation are paid to generator } \\
\text { at the average Local Marginal } \\
\text { Price }\end{array}$ & \multicolumn{2}{|c|}{$\begin{array}{l}\text { Energy fed to the grid is paid at the hourly } \\
\text { Local Marginal Price }\end{array}$} \\
\hline Meter aggregation: & $\begin{array}{l}\text { Collective and Community DG } \\
\text { compensation schemes are being } \\
\text { developed by CRE under the new } \\
\text { regulatory framework }\end{array}$ & Not applicable & \\
\hline $\begin{array}{l}\text { Clean energy } \\
\text { certificates (CELs): }\end{array}$ & \multicolumn{3}{|c|}{$\begin{array}{l}\text { Allocated to the electricity supplier (the DG owner does not retain CELs) } \\
\text { Agreement between electricity supplier and DG owner is required }\end{array}$} \\
\hline
\end{tabular}

Ultimately, the potential magnitude of rate-related impacts can vary substantially depending on the technology chosen, the size of the generator, charges for distribution feasibility studies, interconnection application fees, and the specifics of the distribution network's rate structure. Most customers will likely opt for NEM given the relative economics of net metering compared to other mechanisms available in Mexico. Based upon international experiences with NEM to date, it is unlikely that Mexico will see any significant cost shifting, retail rate, or revenue impacts to CFE due to DG in the near-term as these issues tend to emerge at much higher levels of DG penetration than has currently occurred in Mexico (Woolf et al. 2016; Linvill \& Brutkoski 2017; Satchwell et al. 2014).

\section{Retail Rates in Mexico}

Retail rates are a key component of compensation mechanisms and can influence customer behavior. Their design influences the value proposition of a DG system for customers because the rates represent the costs customers can avoid by self-consuming electricity from their DG systems. Rates are important to consider when creating DG policy in Mexico. 
The public service retail rates in Mexico are divided by sector and voltage level. Other factors that affect the rates are location, temperature zones, and consumption levels. For DG projects interconnected at low and medium voltage levels, there are six main consumer groups: residential, public service, agricultural, commercial, and medium-size industry.

A detailed overview of current retail rate structures in Mexico is provided in the appendix of this report. Mexico's regulator, CRE, is working on modifying and simplifying retail rates and the government is also considering alternatives to reduce the subsidies currently included in these retail electricity rates. A new retail rate scheme was implemented for all sectors except residential customers at the end of 2017 (CFE 2017). ${ }^{15}$

\subsubsection{Summary of Barriers}

Retail rate structures in Mexico are a strong determinant of the value of DG to potential owners. Currently, lower-usage residential customers (Tariffs $1-1 \mathrm{~F}$ ) pay a highly subsidized per-kWh rate and therefore have an artificially reduced economic incentive to pursue DG. The same can be said for agricultural customers and some public services users (5A and 6). One proposed concept that addresses this disconnect is the "bono solar," a method of redirecting tariff subsidies to support distributed solar investment (see section 3.9). Other strategies such as rate design changes or targeted incentives for subsidized customers could also be considered, but evaluation of their impacts on ratepayers is prudent.

\subsection{Establish Direct Financial Incentives}

Under some circumstances, direct financial incentives may be appropriate to jumpstart a DG market. Such support policies may accelerate deployment provided other market barriers are not present, and can be offered broadly, or tailored to specific customer segments (e.g., residential customers) or system sizes (e.g., smaller than $10 \mathrm{~kW}$ ). By providing a direct financial incentive, governments can lower the cost of acquiring DG systems for consumers, encourage the deployment of more DG, and also attract more investment to the DG industry. However, these direct financial incentives require the expenditure (or foregoing) of government funding and/or the expenditure of ratepayer funding.

At a high level, direct financial incentives can be offered as cash payments, tax credits, or tax exemptions (e.g., sales or import tax exemptions). Tax credits require the recipient to have sufficient tax liability to realize the full benefits. Tax exemptions for equipment purchases or labor needed for installation are also a possibility. The typical financial incentive structures are shown in Table 3.

${ }^{15}$ See: Nuevo esquema tarifario (Diciembre 2017-2018) 
Table 3. Common Financial Incentive Structures

\begin{tabular}{|c|c|c|}
\hline Type & Description & Examples \\
\hline $\begin{array}{l}\text { Investment-based } \\
\text { Incentives }\end{array}$ & $\begin{array}{l}\text { Upfront, fixed percentage of total DG } \\
\text { project capital expenditure (\%) } \\
\text { Accelerated depreciation of capital } \\
\text { investments reduce income subject } \\
\text { to taxes and as a result, a company's } \\
\text { tax liability } \\
\text { Sales tax exemptions that lower } \\
\text { purchase price }\end{array}$ & $\begin{array}{l}\text { The federal Investment Tax Credit (ITC) } \\
\text { in the United States provides a tax credit } \\
\text { equal to } 10 \%-30 \% \text { of the capital cost of } \\
\text { renewable electricity systems. }{ }^{16} \\
\text { The Modified Accelerated Cost Recovery } \\
\text { System (MACRS) in the U.S. allows } \\
\text { businesses that acquire a PV system to } \\
\text { depreciate their investment over a 5-year } \\
\text { period. }{ }^{17} \\
\text { In the state of Washington in the United } \\
\text { States, customers are exempt from } \\
\text { paying state sales tax on purchased } \\
\text { clean DG systems under } 10 \mathrm{~kW} \text { (DSIRE } \\
\text { 2017). }\end{array}$ \\
\hline $\begin{array}{l}\text { Capacity-based } \\
\text { Incentives }\end{array}$ & $\begin{array}{l}\text { Upfront, credit for every } \mathrm{kW} \text { of DG } \\
\text { electricity installed [pesos/kW] }\end{array}$ & $\begin{array}{l}\text { In the United States, the New York State } \\
\text { Energy Research and Development } \\
\text { Authority (NYSERDA) provides a cash } \\
\text { rebate of } \$ 0.50 \text { for every watt of } \\
\text { residential solar installed, up to } 25 \mathrm{~kW} \\
\text { (DSIRE 2017). }\end{array}$ \\
\hline $\begin{array}{l}\text { Production-based } \\
\text { Incentives }\end{array}$ & $\begin{array}{l}\text { Ongoing, credit for every kWh of DG } \\
\text { electricity produced [pesos/kWh] }\end{array}$ & $\begin{array}{l}\text { Many states in the United States have } \\
\text { renewable portfolio standards (RPS) in } \\
\text { which renewable energy certificates } \\
\text { (RECs) or solar RECs (SRECs) are used } \\
\text { to track compliance and represent a } \\
\text { production-based financial incentive. The } \\
\text { state of Massachusetts in the United } \\
\text { States requires distribution utilities to } \\
\text { purchase Solar Renewable Energy } \\
\text { Credits (SRECS) from DG solar owners } \\
\text { (DSIRE 2017). SRECs have a market- } \\
\text { based value. } \\
\text { Germany's feed-in-tariff, established in } \\
2000, \text { required that utilities enter long- } \\
\text { term contracts with DG owners at } \\
\text { specific rates (initially well above the } \\
\text { retail rate of electricity) for a set period } \\
\text { (e.g. } 20 \text { years). The feed-in-tariff buy } \\
\text { back rate has been modified multiple } \\
\text { times as market conditions and } \\
\text { deployment has changed (IEA, 2016). }\end{array}$ \\
\hline
\end{tabular}


Table 4 includes possible sources of funding for direct financial incentives.

Table 4. Incentive Funding Sources

\begin{tabular}{|c|c|c|}
\hline Type & Description & Example \\
\hline $\begin{array}{l}\text { Tax credits, } \\
\text { deductions and } \\
\text { exemptions }\end{array}$ & $\begin{array}{l}\text { Tax credits and deductions reduce } \\
\text { the project owner's tax liability and } \\
\text { are a common incentive for } \\
\text { renewable energy. Tax credits can } \\
\text { be offered at both the federal or state } \\
\text { level. They are expressed either as } \\
\text { a percentage of the initial cost of the } \\
\text { project or are earned over time on a } \\
\text { per kWh basis. Tax exemptions are } \\
\text { also common as governments can } \\
\text { exempt renewable energy projects } \\
\text { from sales taxes, import taxes and } \\
\text { property taxes. }\end{array}$ & $\begin{array}{l}\text { In the United States, there is both a } \\
\text { federal investment tax credit (ITC) and a } \\
\text { federal production tax credit (PTC). The } \\
\text { ITC is currently a one time, } 30 \% \text { credit of } \\
\text { qualified expenditures whereas the PTC } \\
\text { is approximately } \$ 0.02 / \mathrm{kWh} \text { for } 10 \text { years. } \\
\text { Colombia has a } 50 \% \text { ITC that is } \\
\text { monetized over } 5 \text { years. } \\
\text { New York state offers a state tax credit } \\
\text { for residential solar of } 25 \% \text { with a limit of } \\
\$ 5,000 \text {. } \\
\text { Dozens of U.S. states exempt solar } \\
\text { projects from both property and sales } \\
\text { taxes. Many countries also exempt } \\
\text { renewable energy technologies from } \\
\text { import and customs taxes such as Peru } \\
\text { and Colombia. }\end{array}$ \\
\hline $\begin{array}{l}\text { Ratepayer Funds } \\
\text { (Wires Charge) and } \\
\text { Utility Settlement } \\
\text { Funds }\end{array}$ & $\begin{array}{l}\text { Ratepayers in the utility service } \\
\text { territory often finance incentive } \\
\text { programs through additional fees on } \\
\text { their utility bills. In addition, utilities } \\
\text { may be obligated to fund incentive } \\
\text { programs as a result of various } \\
\text { settlements and agreements with the } \\
\text { local utility commission. }\end{array}$ & $\begin{array}{l}\text { In the state of Massachusetts in the } \\
\text { United States, all ratepayers ultimately } \\
\text { finance utility compliance with SREC } \\
\text { requirements through a tariff rider. In } \\
\text { New Hampshire, utilities who fail to meet } \\
\text { their RPS obligations make alternative } \\
\text { compliance payments which go to fund a } \\
\text { solar rebate program. }\end{array}$ \\
\hline $\begin{array}{l}\text { Direct Government } \\
\text { Budget support }\end{array}$ & $\begin{array}{l}\text { While less common, governments } \\
\text { can use its own funds to support } \\
\text { incentives for renewable energy } \\
\text { projects. These funds may also } \\
\text { come from international donors. }\end{array}$ & $\begin{array}{l}\text { An example of direct government } \\
\text { support for renewable energy was the } \\
\text { United States } 1603 \text { Treasury Grant } \\
\text { program which paid cash grants of up to } \\
30 \% \text { of qualified investment costs upon } \\
\text { placement in service. The percentage } \\
\text { paid out was based on the technology } \\
\text { deployed. }\end{array}$ \\
\hline
\end{tabular}

\footnotetext{
${ }^{16}$ Legislation passed in 2015 scheduled a credit percentage ramp-down between 2017 and 2022 depending on the technology.

17 Legislation passed at the end of 2017 increased the amount of an asset’s value one could depreciate from 50\% to $100 \%$.
} 


\section{Lessons Learned}

A general lesson gleaned from international experiences across many aspects of electricity policy is that policies must be carefully designed to provide the precise desired incentive. In the case of the financial incentive structures outlined above, each type of incentive encourages a specific behavior and may have its own corresponding tradeoffs.

Investment-based Incentives: By offering to reduce the upfront capital expenditure of a DG project, investment-based incentives can reduce the burden (in part) of a large capital expenditure for DG owners. Importantly, these incentives place no expectation on the size, quality/efficiency, or expected production of the DG system - they are only intended to reduce the upfront capital cost.

Capacity-based Incentives: By offering an upfront incentive based upon the installed capacity of the DG system, capacity-based incentives can function similarly to investment-based incentives. This policy incentivizes watts installed, which could (arguably) be more useful at creating demand for more capacity and/or sizing larger systems for customers. If a government capacity target for DG exists, this is perhaps the most direct form of financial incentive that can be offered to achieve that goal.

Production-based Incentives: Direct financial incentives that are paid on a per-kWh basis specifically motivate DG production rather than installed capacity or investment. This theoretically encourages the installation of systems with higher production efficiency and at lower cost, and may be a useful tool if generation-based public policy goals exist. Unlike other incentive types, production-based incentives are notably paid out over time as opposed to an upfront expenditure.

\subsubsection{Summary of Existing Mechanisms in Mexico}

Mexico has a Federal Clean Energy Standard (akin to a RPS in the U.S.) with clean energy targets for electricity generation of $25 \%$ for 2018, 30\% for 2021 and 35\% for 2024 . As of the June 30, 2017, clean energy generation in Mexico accounted for $20.82 \%$ of total electricity generation (Rodríguez 2017). To promote the growth of clean energy resources, SENER established CEL obligations (akin to RECs or SRECs in U.S.) as a percentage of energy sold by load-serving entities, or of energy consumed for large consumers buying directly from the wholesale market. In other words, suppliers and large consumers are required to purchase CELs. Obligations increase from 5\% in 2018, to $13.9 \%$ in 2022.

Clean power plants receive one CEL for every MWh of electricity generated without the use of fossil fuels. CELs can be traded in the wholesale market operated by CENACE, or can be acquired in long-term agreements (for example in auctions). For a DG owner who shares a meter with a load serviced by a Basic Supplier, the CELs produced by their DG system belong to the DG owner; however, the DG owner is restricted to selling the CELs exclusively through the Basic Supplier. In the current arrangement, only the price for CELs must be freely negotiated between the DG owner and the Basic Supplier.

Clean distributed generation is also eligible for Mexico's accelerated depreciation mechanism that was incorporated into Mexico's income tax law in January 2016. The law allows taxpayers to deduct $100 \%$ of the value of a system purchased in a given fiscal year for corporate income 
tax purposes. If the accelerated depreciation creates a net operating loss (NOL), which is likely, the NOL can be carried forward for up to ten years to offset future corporate income taxes. At the end of 10 years, any remaining NOL can be written off (Martinez 2016).

\subsubsection{Summary of Barriers}

The barriers listed below focus on Mexico’s main existing direct financial incentive: CELs.

- Market prices for CELs are expected to be quite low in the near-term as indicated by recent CENACE auctions. Thus, CELs are not expected to be a strong financial incentive for clean DG deployment. However, at this stage it is unclear if they are necessary or can be considered a high priority measure to incentivize deployment.

- Clean DG owners are currently restricted to selling CELs to their electricity supplier. If DG owners do not have enough information about the price of CELs, there is a risk that they will be undercompensated for CELs.

- DG owners who wish to be credited for CELs need to install an additional meter to measure gross energy generated by the system. This cost could be an additional barrier for DG owners to benefit from CELs.

- Motivating new government funding for DG may be politically difficult to accomplish in Mexico, given other demands for funding and priorities.

\subsection{Expand Access to Financing of DG Options}

An alternative to direct financial incentives is the implementation of financing schemes that can successfully alleviate the initial capital cost barrier of installing DG for the consumer.

Despite rapidly declining prices, a DG system is still a significant capital expense for prospective consumers. Without financing options, DG market growth in Mexico may be limited to high-income customers who can afford such a large investment, a situation which runs counter to Mexico's goal of increasing energy democratization and consumer choice. By expanding access to DG financing options, Mexico can attract additional capital to the DG sector.

Loans allow customers to finance a DG system and use electricity savings to offset loan payments (Feldman and Lowder 2014). Low-interest loans can be offered directly by the state or federal government. Private and public banks, vertically integrated developers, and specialized financial institutions such as green banks ${ }^{18}$, are other sources of loans. Loans can also be made for clean energy projects from revolving loan funds, established by governments, in which capital from repaid loans is re-loaned for other clean energy projects (DOE, n.d). Governments can also offer credit enhancements which reduce credit risk through various mechanisms and loan guarantees can also expand access to financing DG (Cox 2016).

Property-assessed clean energy (PACE) is another innovative DG financing model that allows a private property owner to pay back upfront DG (or energy efficiency) investments over time via

\footnotetext{
${ }^{18}$ A "green bank" is a financial institution that deploys low-cost capital specifically for clean energy projects. In addition to loans, green banks can offer products such as credit support mechanisms and property assessed clean energy (PACE) (NREL, n.d.). See “Green Banks" for more information.
} 
additional property tax payments. Property values, rather than individual credit scores, determine the credit risk for PACE participants (Speer and Koenig 2010).

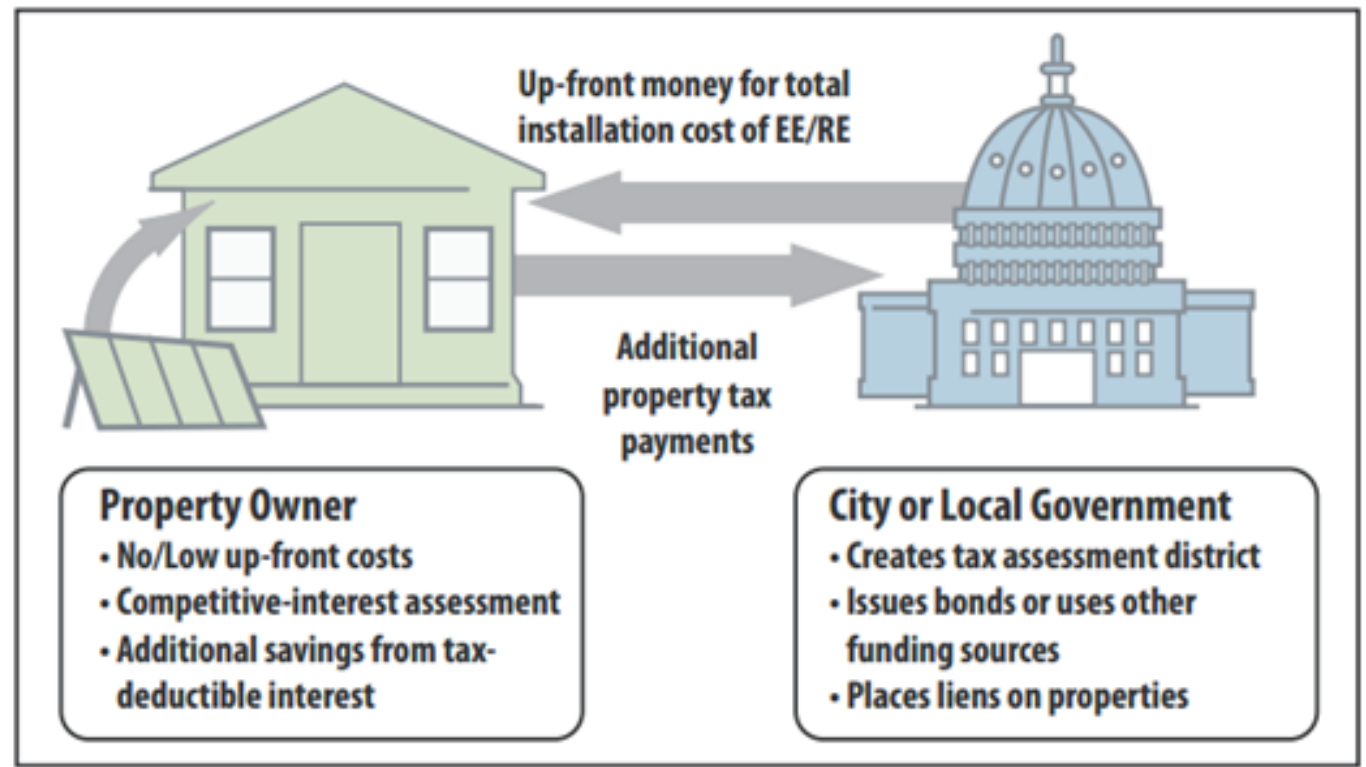

Image from Speer and Koenig (2010)

Figure 5. Basic PACE Financing.

On-bill financing, also called on-bill recovery, is another financing method that can reduce complexity for customers and expand customer access to DG because it is less reliant on credit scores. On-bill financing is a mechanism that allows a customer to repay an energy efficiency or renewable energy investment directly on his or her utility bill. Either a utility or third-party provides a customer with a loan for DG which the customer then pays back over time via utility bill payments. This method helps customers avoid upfront payments for DG; the energy savings a customer sees from DG will likely exceed the monthly loan payment.

Third-party ownership, discussed in section 3.4.1, can help the customer avoid a large upfront payment through leasing and power purchase agreements.

\subsubsection{Summary of Existing Mechanisms in Mexico}

Financing mechanisms available in Mexico include:

Distributed Clean Energy Technologies Financing (FATERGED ${ }^{19}$ ): The objective of the FATERGED is to accelerate the availability of domestic credit to potential DG adopters. In 2015, the government committed 120 million pesos ${ }^{20}$ to promote access to renewable distributed generation technologies, of which 96 million pesos will be used for Partial Credit Guarantee (PCG). The design of the program will be operational by December 2017, and it is expected to mobilize large financial flows towards the distributed solar sector (leverage ratio 10:1) by

\footnotetext{
${ }^{19}$ Financiamiento para Acceder a Tecnologías de Energías Renovables de Generación Eléctrica Distribuida (FATERGED)

${ }^{20}$ Approximately $\$ 7.6$ million USD.
} 
diminishing investors and financiers' perception of risk. The PCG will be available for investors and financiers by request from a national development bank that is still to be determined.

DG Support Program: Through this financing program, FIDE has supported 1,057 DG projects, representing more than 227 million pesos, and a total of 6.89 MW of installed capacity (FIDE, 2017a). Using resources from the Energy Transition Fund (FOTEASE), FIDE supports residential and SMEs consumers directly by granting a direct financial incentive of $10 \%$ of the total system cost and the remaining $90 \%$ is loaned at preferential rates with resources from FIDE (FIDE 2016). The project must have a simple payback period of 6 years and the PV modules must have FIDE's energy saving certification (further discussed in Section 3.5.1) to qualify.

\section{Program of Integral Sustainable Improvement in Existing Housing (Programa de} Mejoramiento Integral Sustentable en Vivienda Existente): SENER launched this program in 2016 to offer workers earning up to five times the minimum wage loans of up to 50,000 pesos to retrofit houses with energy saving technologies, such as solar heaters and PV systems (CONAVI 2017). The loans have fixed interest rates from $14 \%$ to $18 \%$ before taxes, a five-year term, and may include an incentive for $40 \%$ of total costs.

\section{Green Mortgages_by the_Mexican Federal Institute for Worker's Housing (Infonavit):}

Infonavit administers a trust funded by the contributions of most salaried employees in Mexico. Infonavit grants low-interest mortgage loans to qualifying people based on their contributions. The law requires that all housing financed by Infonavit have features or appliances that save electricity, water, and gas.

During 2015, 376,433 credits were granted under the green mortgage framework (96\% of all mortgages), reaching an accumulated amount of 2,173,856 credits granted with green mortgage. The green mortgage promotes the efficient use of electricity, gas, and water by providing an additional amount to the housing credit in order to invest in a house with efficient technologies aimed at reducing family expenses, optimizing the use of resources, and contributing to the reduction of greenhouse emissions. During 2015, photovoltaic systems connected to the grid were added to the "eco-technologies" catalog, consolidating the green mortgage program as the main eco-technologies financing mechanism in Mexico.

Shared-risk Trust (Fideicomiso de Riesgo Compartido, FIRCO) ${ }^{21}$ : The specialized Sharedrisk Trust promotes the use of renewable energy and energy efficiency in the agricultural, livestock, fisheries, and food sectors in Mexico by mixing and complementing resources from Secretaría de Agricultura, Ganadería, Desarrollo Rural, Pesca y Alimentación (SAGARPA), the World Bank and the Global Environmental Facility (GEF). FIRCO aims to support projects using bioenergy, renewable energy, and energy efficiency.

From 2008 to 2012, FIRCO authorized 715 million pesos for the support of 1,614 projects across the country, including 555 PV systems for water pumping and refrigeration (FIRCO 2012). From

\footnotetext{
${ }^{21}$ FIRCO is a specialized shared-risk trust created by presidential decree and sectorized to SAGARPA (Secretariat of Agriculture, Livestock, Rural Development, Fisheries and Food of Mexico), to promote agribusiness, rural development in micro-watersheds and to serve as a technical agent in the agricultural and fisheries sectors.
} 
2013 to 2015, 52 new PV systems were installed, and 9 additional projects were underway in 2016 (FIRCO 2016).

\subsubsection{Summary of Barriers}

- According to participants at the July 6, 2017 Mexico Distributed Generation Public Policy Workshop in Mexico City, it appears that most DG systems are cash financed and those that are not face high interest rates on loans. Generally speaking, financing from private banks in Mexico is still not widely available for DG systems.

- Under the Program of Integral Sustainable Improvement in Existing Housing, the interest rate of $14.5 \%$ offered to low-income customers may be too high, and a loan term of 5 years may be too short given the lifetime of DG assets.

- The availability of the different financing offerings highlighted above is not well known among many customers.

- PV systems offered in the "Green mortgage” program are relatively expensive compared to other eligible measures in the program.

\subsection{Expand Customer Access to DG Options}

One goal of Mexico’s energy reform is to move toward more market-based regulation and expand customer choice. At the moment, DG adoption is nascent in Mexico and barriers to DG market participation among various customer segments remain. On top of tariff reform, direct financial incentives and expanding the availability of financing, to encourage meaningful DG adoption across multiple market segments, the government of Mexico may need to enable alternative business models such as third-party ownership, solar leasing, or shared solar, including specific strategies for low-income customers, and targeted programs for subsidized customers with no incentive to install DG. These concepts are discussed below. Increasing the size of the market by allowing DG leasing options and shared renewable programs will attract financing.

Third-party Ownership: Third-party ownership models, popular in many U.S. states, allow customers to deploy solar and pay lower electricity bills by making a monthly payment, less than his or her original electric bill, to a solar company. The payment can be in the form of a power purchase agreement or a lease. A third-party owner uses its own upfront capital to procure, finance, and own a project instead of the consumer. Often solar companies are able to more efficiently monetize any available tax credits than individual consumers and may pass along these savings to consumers. In the United States, third party ownership models have been a primary driver of distributed solar market growth. As of 2017, third-party owned ownership has slowed in the U.S. to represent $40 \%$ of new installed capacity and is expected to continue dropping to 24\% by 2022 as solar loan providers become more prevalent (GTM/SEIA 2017). The percentage of third party owned systems is declining as solar costs decline because more consumers are able to bank-finance the cost of the project, benefit directly from the tax incentives (which are also smaller in dollar terms as solar costs decline) and solar companies look to increase their direct cash sales at the expense of longer term PPA and lease transactions.

Shared Solar: Shared solar (also known as community solar or solar gardens) is an innovative business model that has expanded customer DG access in the United States. Customers who 
cannot install on-site rooftop DG for whatever reason (e.g. renters, poor roof quality, shading issues, apartment dwellers) or simply do not want to install rooftop DG can subscribe to a portion of an off-site (rooftop or ground-mounted), shared solar project and receive bill credits virtually. Like traditional rooftop DG, shared solar customers can purchase their share outright, or, where available, use a solar lease or PPA. Typically, larger shared solar systems are less expensive (per $\mathrm{kW}$ ) than rooftop systems because they enjoy economies of scale. Shared solar projects can also be sited in optimal places to mitigate grid congestion or on previously disturbed land such as brownfields and can be better managed and tracked by utilities. Utilities, third-party developers, and community or nonprofit organizations have all developed shared solar programs in the United States. The participants and transactions in a typical third-party shared solar model are shown in Figure 6.

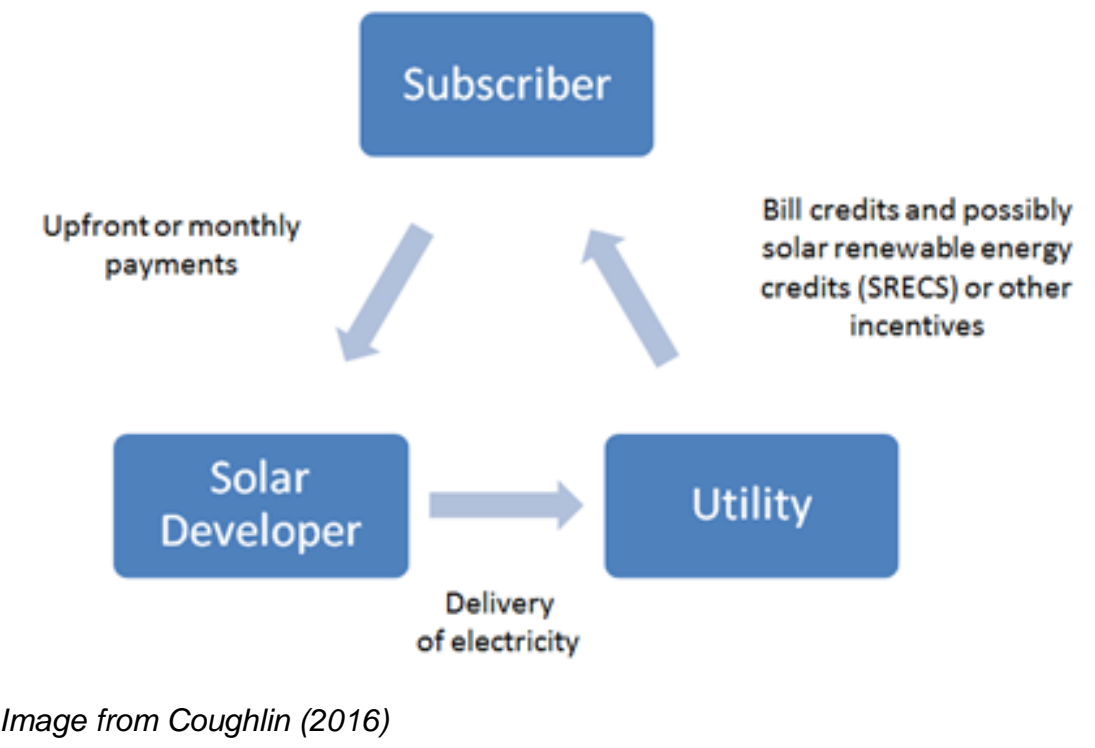

Figure 6. Typical third-party developer community solar model.

Shared solar has seen increasing market growth in the United States and this trend is expected to continue. States such as Colorado, Massachusetts, Minnesota, and California, with shared solar enabling legislation are top state markets in terms of operating and planned shared solar capacity (Honeyman et al, 2017). Public sector entities, such as local governments and universities in the United States, who cannot directly take advantage of DG tax incentives have been notable participants in shared solar programs.

Virtual Net Metering Policies: Virtual net metering allows customers to take advantage of the same compensation mechanism and billing schemes as net metering without requiring their distributed PV to be on-site. Multiple customers' load can be offset by the excess generation and net metering credits produced by a single PV system. Net metering credits appear on a customer's bill as if the distributed PV were actually located on his or her property. Virtual net metering is a primary enabling policy supporting the growth of the community solar market in the U.S. (Coughlin et al. 2012). Many U.S. states (shown in blue in Figure 7) have also adopted policies that allow for the aggregation of multiple meters under a net metering tariff. This policy is growing in popularity in the United States and may be worth considering in Mexico. 


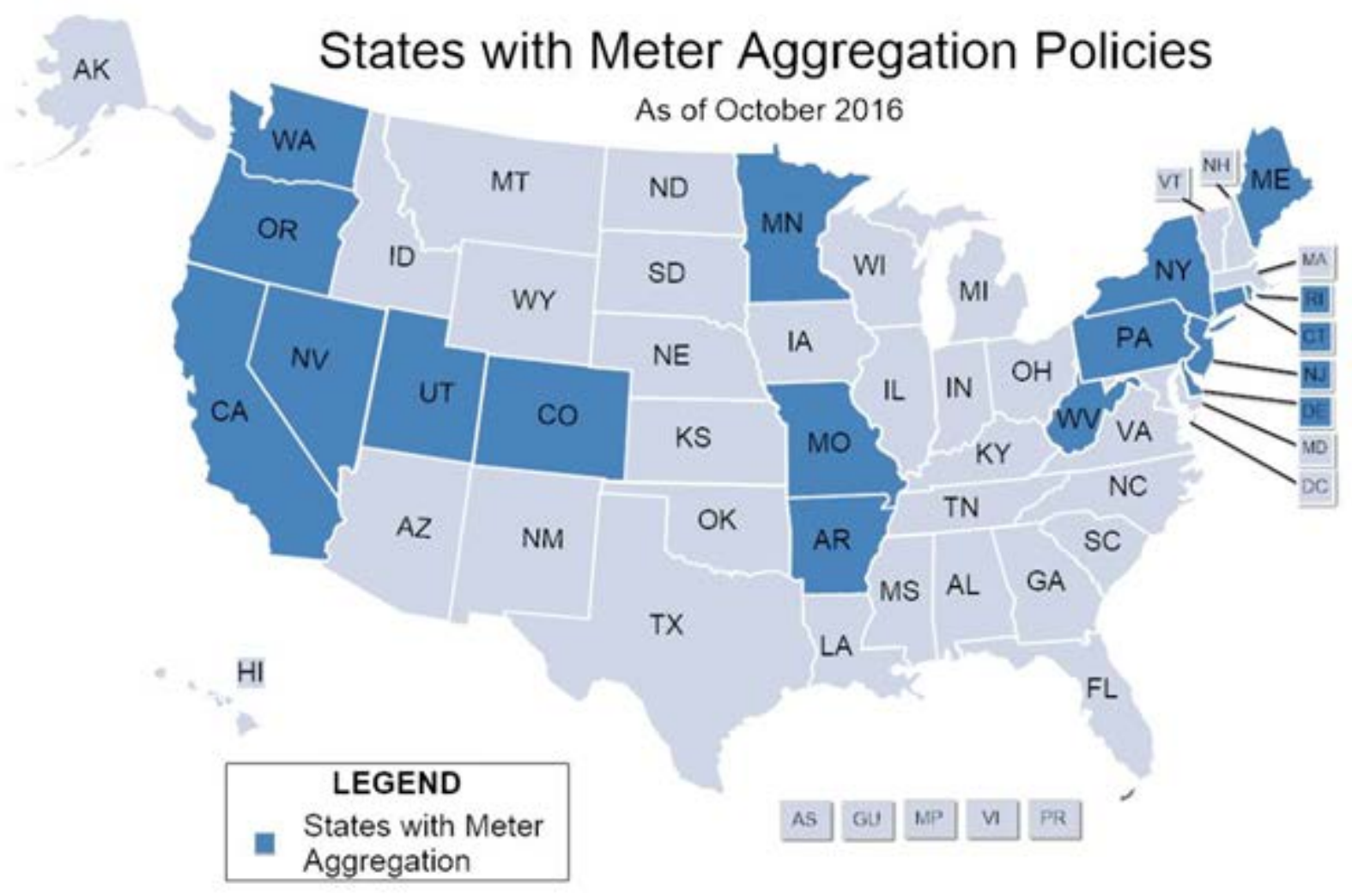

Image from DSIRE

Figure 7. States with Meter Aggregation Policies.

Low-Income Strategies: Even in jurisdictions with significant DG installed capacity and vibrant DG markets, many low-income customers still do not have access to DG because of numerous barriers that moderate and high-income customers do not face. Low-income customers may lack access to capital, have insufficient tax burdens to take advantage of DG tax incentives, may rent rather than own their homes, and already receive subsidized electricity rates that distort the market signal to invest in DG. There are a variety of approaches to expanding this customer segment's access to DG including providing direct DG incentives, providing publicly-backed loan loss reserves for DG loans, revised underwriting criteria for DG loans, and on-bill financing. Redirecting electricity assistance program funding to subsidize DG investments is another approach some states in the United States are experimenting with. Multifaceted approaches may offer the best solution (NREL 2017).

In the U.S., utility ownership of DG is also currently being explored to support low-income customers. In these instances, rooftop solar systems are being deployed on the roofs of lowincome customers, with the utility providing a rooftop rental payment and oftentimes free electricity or bill credit to the customer.

\subsubsection{Summary of Existing Mechanisms in Mexico}

Third-party Ownership of DG in Mexico: The Electricity Industry Act allows third parties to own DG systems for on-site consumption. In this case, the relationship between the third party and the consumer is not considered commercialization, which avoids the taxation and regulation 
that commercial transactions are subject to. Third-party owned systems can use the three existing DG compensation mechanisms in Mexico.

Shared Solar in Mexico: In 2012, CRE published a collective interconnection contract for low voltage DG for buildings with several loads sharing one interconnection point. This compensation scheme allowed different customers in a single location to collectively install a DG system to offset their electricity consumption through net metering. Third-party ownership is not allowed under the current shared solar policy.

CRE is currently developing the collective and the community NEM compensation mechanisms. The collective NEM mechanism applies to buildings many tenants with a common interconnection point, and the community NEM mechanism applies to DG systems that offset aggregated loads, independently of the location of the loads and the system.

\subsubsection{Summary of Barriers}

- There is not currently a regulation for shared solar programs in Mexico

- There is not currently a virtual net energy metering scheme offered in Mexico.

\subsection{Encourage the Maturation and Quality of Suppliers, Materials and Labor}

A robust DG market requires a well-trained workforce that includes electricians, installers, sales personnel, and marketing professionals, among others. Training and certification programs can support workforce development and underlying policy signals can create a steady flow of projects. In addition to a specialized workforce, high quality DG materials and suppliers can also build confidence among prospective DG consumers and capital markets and can bolster longterm public support for DG. Governments can partner with industry and universities to provide relatively inexpensive solutions to enable high-quality suppliers, materials, and labor.

\subsubsection{Summary of Existing Mechanisms in Mexico}

CRE is mandated by the Electric Industry Act to promote the training of DG installers.

Additionally, the Energy Transition Act states that SENER, CRE, CENACE and CONUEE must establish and adjust hardware, performance, and installation requirements for clean DG systems; elaborate labor and company certification regulations; promote capacity building; and establish a certification program for companies, their personnel, independent professionals, and technicians.

Furthermore, the Federal Law on Metrology and Standardization (Ley Federal de Metrología y Normalización), establishes that there are two types of norms: Official Mexican Norm (NOM), and Mexican Norm (NMX). NOMs are mandatory, while NMXs are recommendations of parameters or procedures. The government of Mexico has a series of NXM for DG related to electricity, PV modules manufacturing and performance (SE 2017).

To date, there are no mandatory norms or certification schemes or training programs for DG installers, however, several institutions that implement DG financing have technical requirements for installer training and equipment quality. 
FIDE Certification: Clean energy products and technologies must comply with FIDE's quality, safety, and performance standards to be certified. Specifications for compliance are formulated through a specialized group of providers, which consider technical information of the products, compliance with Official Norms, and accredited laboratories. For PV systems, this includes specifications for PV panels and inverters, establishing minimum efficiencies, safety, quality, and other technical characteristics.

FIDE and CONOCER: The Public Education Ministry (SEP) coordinates the National Competence System (NCS) which is aimed at increasing the level of economic competitiveness, knowledge development, and social progress in Mexico. To that end, the NCS promotes the integration of committees, which develop professional competence standards (CONOCER 2016).

One of the committees working under the CONOCER program is the Renewable Energy and Energy Efficiency Competences Management Committee, which is responsible for developing human resource competence standards and technical certifications. The Committee is made up of 40 members from academia, private and public sectors, and international organizations, and has developed four standards related to renewable energies since 2012.

Installers must be certified by FIDE in order to gain access to the financing programs offered by FIDE. FIDE has certified 277 professionals so far (FIDE 2017b).

Infonavit and ANCE: In 2012 the Asociación de Normalización y Certificación (Normalization and Certification Association - ANCE) published the Technical Safety and Operation Specifications for PV projects and installations (ANCE-ESP-02), with the objective of determining the minimum requirements for the grid connected PV systems for domestic use (housing). The specification contains safety requirements for the installation, operation tests, user guaranty, and the fulfillment of all technical specifications required by the distribution company. The ANCE-ESP-02 is applicable to all housing developers who want to participate in the Infonavit financing program, and/or any other program offering housing with PV systems with capacity below $30 \mathrm{~kW}$. ANCE offers the service to certify providers of PV systems, following the ANCE-ESP-02 specifications. Currently, three companies are certified by ANCE, while an additional 19 companies have begun the registration process (ANCE 2017).

FIRCO and ANCE: To access the financing and incentives offered by FIRCO, project developers are required to be certified as verified suppliers. According to the selected technology, every project developer must complete the requirements to receive the certification, which is granted by ANCE. There are at least 90 suppliers with the certification, while more than 480 are in the process of becoming certified (SAGARPA/FIRCO 2017).

SENER/GIZ Reliable Supplier (Esquema de Proveedor Confiable): SENER and GIZ are currently working on a scheme to standardize the requirements for service providers among the different public institutions that implement financing programs (FIDE, Infonavit and FIRCO). The objective is to develop a common valuation and certification scheme for Renewable Energy and Energy Efficiency Providers, with the support of the Mexican Entity of Accreditation (Entidad Mexicana de Acreditación, A.C.). It is expected that this scheme will not only provide the market with needed certainty, it will also save time in the evaluation of projects. 


\subsubsection{Summary of Barriers}

- Lack of uniform and legally binding set of national installer certification and equipment standard requirements and processes

- Lack of awareness of norms and minimum standards by the customers, given the complexity and redundancy of the normalization and certification system

- Lack of certified installers, given the different processes of certification for each program. In the case of the "Green mortgage" program by Infonavit, there is a limited number of certified installers (there are currently 3 certified installers and 19 companies are in the certification process).

\subsection{Establish of Best-Practice Interconnection Procedures}

Distributed generation can impact the reliability and power quality of the low voltage distribution network, so it is imperative that DG interconnection procedures are put in place to ensure the safety, reliability, and quality of the power systems. We define interconnection procedures as the suite of processes and governing technical criteria for the interconnection of DG systems comprising application processes, interconnection screening criteria, triggers for system impact studies (where appropriate), utility impact mitigation activities, and postcommissioning system certification processes. The efficiency and speed at which DG interconnection applications are processed has been identified as a barrier in some markets around the world, because the amount of DG installed is completely determined by how much DG is approved for interconnection by the distribution utility.

Designing these processes can be characterized as a careful balancing act in a desire to pursue process stringency with process expediency. If a process is excessively stringent, this may result in (1) a lengthy and costly approval process which unnecessarily discourages DG deployment and/or (2) DG systems being denied interconnection which would otherwise safely and reliably operate. On the other hand, if a process is excessively expedient for DG customers to interconnect without sufficiently stringent technical requirements, this may lead to the risk of undesirable safety or reliability issues. Public policy can promote interconnection procedures which are sufficiently forward-looking, customer-oriented, technically rigorous, and expediently executed in terms of time and cost.

Around the world, utilities will have distinct technical concerns about the impact of DG on their own system. This is further complicated by the fact that the potential impacts of DG change substantially with each distribution network feeder. Factors for determining the maximum grid hosting potential for a given feeder are numerous, and includes size of each DG system, location of each DG system, impedance of feeder, local cloud variability, location of capacitor banks, line regulation configuration, and presence of other DG and loads, among others.

One relatively universal experience among distribution utilities is that ex ante fears of technical impacts from DG tend to be significantly overstated relative to what commonly occurs in practice. DG technical impacts are usually quite small, particularly for the first several years of a program, and can be managed (when informed by good data collection) within regular distribution network planning processes. International experience suggests that the expected technical impacts are highly localized to the conditions of the individual feeder, and are generally quite small and manageable for the first several years of a program. 
Establishing an interconnection process requires new administrative tasks by distribution utilities. These include processing applications and evaluating the expected impacts of potential systems. Perhaps the largest burden within this process, from the standpoint of both time and money, is the periodic need to conduct detailed distribution network impact studies. To avoid unnecessary administrative burdens while also promoting expediency, particularly for conducting impact studies, some strategies include:

- Mandate “fast track” interconnection processes for smaller systems

- Mandate the use of multiple layers of quick interconnection screens, rather than a single screen which triggers a requirement for a detailed study

- Mandate "fast track" interconnection processes for locations with shorter feeders

- Mandate that the utility cluster applications on the same feeder and periodically perform screening assessments together to save costs.

To mitigate the possibility of slow utility response times for evaluating interconnection applications or providing detailed impact studies, some strategies include:

- Mandate maximum utility response times for various steps throughout the interconnection process

- Mandate application status tracking (i.e., online, phone, email, or otherwise)

- Mandate an online application process whereby applications can be quickly amended by the applicant once submitted

- Collect data on applications for consumer transparency and accountability purposes (e.g., application processing time for different stages, rejection/acceptance rate, interconnection rate, etc.).

To mitigate the possibility of consumer uncertainty over the viability of their DG application, and to ensure that consumers prepare viable interconnection applications, some strategies include:

- Mandate that online maps are published which illustrate optimal locations for DG systems to be installed on the distribution network

- Mandate the availability of an instant, online, nonbinding "pre-application" report which quickly provides information on the viability of a DG system at a given location to interconnect. Such an online system could query a database to assess relevant technical aspects such as: how close the system is to the nearest feeder, existing feeder DG penetration, the maximum DG capacity that can be installed in location, etc.

As DG penetration increases, integrating DG resources will require investments by the distribution utility. These investment decisions must be informed by robust distribution network planning which accounts for existing and future installations of DG, which in turn requires good data. Government strategies to encourage the collection of this data include: 
- Mandate that minimum data collection metrics (e.g. GIS, location, size, technology, panel orientation, etc.) be incorporated in an interoperable database that interfaces with existing utility GIS and modeling systems; mandate data collection even if utility data system is not yet functional

o Many utilities in the United States had to "play catch up" with DG data collection, as they did not realize the value of this data until feeder penetrations began to increase significantly. Without this data, it may be quite difficult to evaluate the hosting capacity of individual feeders.

\subsubsection{Summary of Existing Mechanisms in Mexico}

In Mexico, the Electric Industry Act established that DG projects will have open and not unduly discriminatory access to: (1) the general distribution networks and (2) the competitive market where they may sell their energy production. Furthermore, it established that in typical cases, requests for interconnection of the DG systems may not require studies to determine the specific characteristics of the required infrastructure. To this end, two instruments regulate the interconnection process for DG projects in Mexico: (1) the Interconnection Manual for Power Plants with Capacity below 0.5 MW (Manual) (SENER 2016c), and (2) the General Administrative Dispositions for Distributed Generation (Dispositions) (CRE 2017b). The Manual establishes general administrative and infrastructure guidelines for DG, while the Dispositions further delineate those guidelines, define standard interconnection contracts, and establish additional technical specifications.

According to the Manual, interconnection requests must be resolved within 13 working days or fewer when no interconnection study is required, and 18 if the study is required. For low voltage interconnection, requests will be automatically accepted after 18 days have passed without a response, if the delay is not caused by the requester. All required activities for the interconnection must consider the times shown in Table 5.

Table 5. Process and times for interconnection

\begin{tabular}{|l|c|c|}
\hline \multicolumn{1}{|c|}{ Activity } & Responsible & Working days \\
\hline Registry of the request & Electricity Supplier & 1 \\
\hline Verification of information & Distributor* & 2 \\
\hline Letter of acceptance when no study or infrastructure is required & Distributor & 4 \\
\hline Letter with study or infrastructure budget & Distributor & 10 \\
\hline Documentation review & Electricity Supplier & 1 \\
\hline Modification of the interconnection infrastructure & Requester & Requester \\
\hline Relocation of meter & Distributor & 5 \\
\hline Sign the agreement & Electricity Supplier & 2 \\
\hline Integration to the commercial scheme & Electricity Supplier & 1 \\
\hline
\end{tabular}

* E.g. CFE Distribución

DG projects that comply with the interconnection schemes and conditions of available capacity in the distribution circuits will not require a study. The Manual establishes available capacity as the sum of net generation capacities not exceeding $80 \%$ of the transformer or feeder capacity in low voltage distribution circuits, and the sum of net generation capacities not exceeding $80 \%$ of the transformer capacity or the feeder capacity in medium voltage distribution circuits. 
For those cases in which a DG project does not comply with the previous conditions and an interconnection study is required, it will be done by CENACE at the expense of the distributor.

The distributor is responsible for anticipating necessary expansion and modernization of the general distribution networks (RGD) for the interconnection of DG. To ensure expediency, transparency, and accessibility, the Dispositions establish a timeframe of 365 days for the distributor to develop a web-based platform for the management of the interconnection process, making it possible to make an interconnection request via the internet. The same platform must have the capability to show statistics about the integration of DG, including the hosting capacity of the distribution circuits and the actual amount of installed capacity. Once available, the platform must be updated every 3 months. When the necessary upgrades are not duly anticipated by the Distributor, the Requester can opt voluntarily to: (1) install them at his or her own expense, (2) install them with contributions to the Distributor or (3) request for the required infrastructure to be included in the expansion and modernization program of the Distributor.

The Manual also mandates that distributed generation systems be formally inspected and certified by "inspection units ${ }^{22}$ " to determine if they meet technical requirements for interconnecting to the distribution system outlined in the Dispositions. These inspection units are authorized by CRE.

\subsubsection{Summary of Barriers}

CRE has clearly established that it is the responsibility of the Distributor to plan and foresee the expansion and modernization requirements to integrate DG, but it remains to be seen whether this planning will take place effectively or if additional measures will have to be considered by the regulator.

\subsection{Promote Locally Manufactured Content}

Some jurisdictions around the world have taken steps to promote the use of locally manufactured content within the clean energy supply chain. Such policies may help to accelerate investment in manufacturing facilities and support job creation; on the other hand, these policies may be considered controversial and in violation of bilateral and multilateral trade agreements. To create a realistic content localization policy, the potential for localization must be studied extensively for a variety of technologies in order to inform goals. Goals can be ramped up over time to further encourage localization and lend confidence to investors of manufacturing facilities.

\section{Direct Financial Incentives tied to Use of Local Content:}

It is also possible to provide some form of direct financial incentive (see Section 3.2) specifically to DG system owners that use locally manufactured content. Like the centralized procurement approach mentioned above, clear metrics and measurement processes must be employed to ensure compliance.

Some states within the United States have taken steps to encourage local DG manufacturing. For example, in 2013, Minnesota initiated its "Made in Minnesota" Solar Incentive Program that provides a 10-year, performance-based incentive to residential and commercial customers in

\footnotetext{
${ }^{22}$ Unidades de Inspección
} 
certain utility service territories who install solar technologies manufactured in Minnesota. Manufacturers interested in qualifying for the program must apply to the state (Minnesota Commerce Department 2017).

A main criticism of local content incentives, like those employed in Minnesota, is that they can end up supporting companies that cannot compete with other producers once the rebates are removed. In the meantime, customers typically purchase DG systems at higher prices with no long-term benefit.

\section{Direct State Support to Manufacturing Facilities:}

In some countries, governments have provided loan guarantees (e.g., in the United States) or direct financing (e.g., China) to support the development of manufacturing facilities. This is a direct way to support the creation of jobs and local manufacturing capacity. Depending on the existing localization potential in Mexico, these measures may or may not be required.

\subsubsection{Summary of Existing Mechanisms in Mexico}

Public Trust to Promote the Development of National Suppliers and Contractors in the Energy Industry by the Secretariat of Economy: In conformity with Article 90 of the Electric Industry Act, the Secretariat of Economy (SE) is responsible for defining the necessary strategies to promote local value chains in the electric industry, with special attention paid to small and medium-sized enterprises (SMEs). To achieve this, this trust was established to provide financing and support schemes in capacity building, research, and certification.

Furthermore, Articles 84 and 86 of the Energy Transition Act (LTE), established that the SE, in coordination with SENER, will design and instrument a roadmap to promote value chains in clean energies and complete a study to determine requirements and the potential for clean energies in the electric industry. To this end, the SE published the Strategy for the Promotion of Local Value Chains and the Direct Investment in Electric Industry and Clean Energies 2016$2017^{23}$, focusing on the following actions:

- Identifying the potential demand for goods and services in generation, transmission, and distribution activities

- Identifying the potential supply for goods and services in generation, transmission, and distribution activities

- Identifying business opportunities and needs for development of national providers and contractors

- Promoting the regional development of the electric sector

\footnotetext{
${ }^{23}$ Estrategia para el Fomento Industrial de Cadenas Productivas Locales y para el Fomento de la Inversión Directa en la Industria Eléctrica y Energías Limpias.
} 
- Reorienting of technical and financial support of the Public Trust to Promote and Develop National Providers and Contractors in the Electric Industry to high impact projects

- Promoting foreign investment.

Manufacturing profile-large scale solar PV technology in Mexico: Promexico, GIZ, Fraunhofer ISE, IER - UNAM are collaborating in the development of a technology roadmap for solar PV as a tool to formulate, implement, and communicate a strategy based on innovation. The preliminary diagnosis of 2014 highlights the following:

- Value of fabrication: the fabrication of crystalline silicon (c-Si) PV modules supported a direct value added of \$367 million dollars to Mexico.

- Commerce: exports and imports of PV modules reached \$534 million and \$132 million dollars respectively, leaving a positive trade balance of $\$ 402$ million dollars. The main commercial partners were China (importing), and the United States and Germany (exporting).

- Manufacturing capacity: at the end of 2015, Mexico had an installed manufacturing capacity of PV panels equal to 1,727.5 MW (see Figure 8).

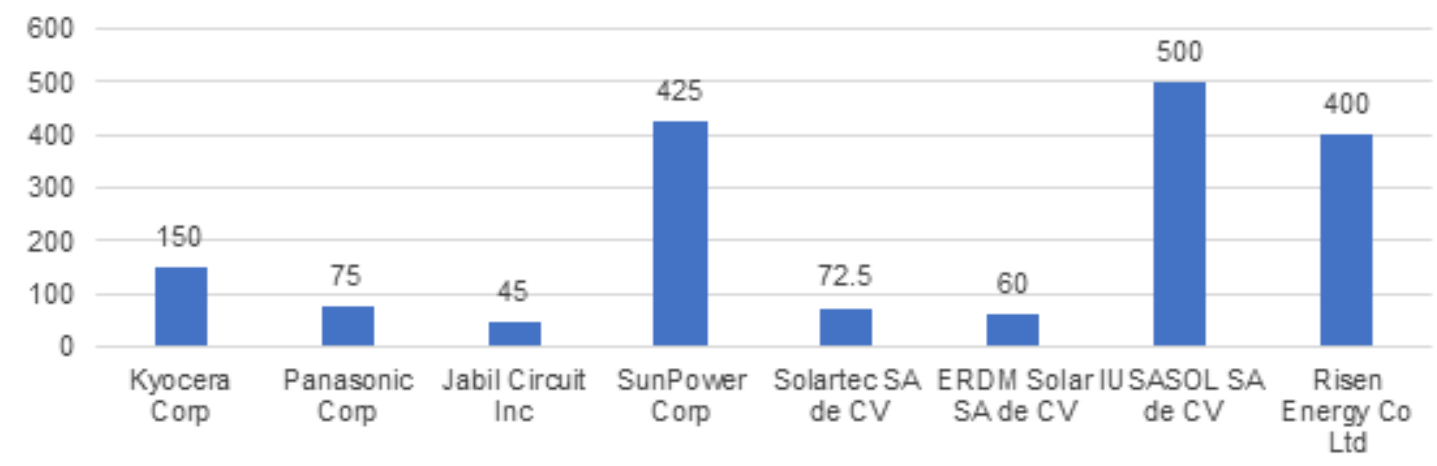

Image from GIZ with information from BNEF

Figure 8. Installed manufacturing capacity of PV panels in Mexico (MW)

\subsubsection{Summary of Barriers}

No barriers identified (stakeholder input strongly encouraged).

\subsection{Encourage Public Awareness of DG}

Customers may choose not to invest in DG simply because they do not understand the potential benefits and costs of the technology. Various barriers can stymie customer awareness of DG including lack of internet access, time constraints, skepticism, unclear or complicated eligibility criteria, or difficulty demonstrating eligibility. There are numerous tools that can be applied to overcome barriers and encourage greater public awareness of DG including public relation campaigns, effective marketing strategies, industry partnerships, online assistance, community outreach, and workshops, among others. 


\subsubsection{Summary of Existing Activities in Mexico}

In Mexico, federal and local government, associations, cooperating agencies and nonprofits have been the main drivers for promoting DG. Although not an exhaustive list, some of the main actors promoting solar DG are the following:

- Asociación de Energía Solar (ANES, Solar Energy Association): Provides a discussion forum for ideas, comparison, exchange, and general dissemination and promotion of the use of solar energy.

- Asociación Mexicana de Energía Fotovoltaica (ASOLMEX, Mexican Photovoltaic Energy Association): Provides a forum for analysis, proposals, and dissemination topics related to solar energy, with a focus on legal and regulatory issues.

- Centro Mexicano de Innovación en Energía Solar (CeMIE Sol, Center for Solar Energy Innovation) CeMIE Sol is a national program that promotes the collaboration of several public institutions with the goal of advancing solar technology.

- Iniciativa Climática de México (ICM, Mexican Climate Initiative): ICM was created with the objective of supporting actions and mitigation policies through philanthropic investment, facilitation of dialogue, production of technical papers and mobilization of resources to elevate and improve investments in climate change mitigation.

- Programa de Fomento de Sistemas Fotovoltaicos (ProSolar, Program to Promote Photovoltaic Systems): ProSolar is a public-private initiative of SENER and the German Technical Cooperation (GIZ), created with the objective of promoting the growth of solar PV.

\subsubsection{Summary of Barriers}

No barriers identified (stakeholder input strongly encouraged).

\subsection{Encourage the Reduction of Electricity Tariff Subsidy Payments}

Governments often subsidize the electricity bills of low-income and/or low energy use customers to ensure that people have access to energy for basic needs. Under some circumstances, deploying DG for subsidized customers presents the opportunity to reduce the level of subsidy payments made by a government without increasing energy costs to the customer. If customers paying subsidized electricity rates are able to deploy DG, their reduced net consumption of kWhs may also translate into savings for the government.

\subsubsection{Summary of Existing Mechanisms in Mexico}

Lower-usage residential customers (Tariffs $1-1 \mathrm{~F}$ ), agricultural customers, and public services customers pay subsidized per-kWh rates, and therefore have an artificially reduced economic incentive to pursue DG. Low-use residential customers, in particular, are largely subsidized by the Treasury Department (Hacienda).

Solar Bonus: Iniciativa Climática de México (ICM) is currently developing a mechanism to repurpose current rate subsidies to finance DG systems (Chacón n.d.). The core idea of the mechanism is to provide an incentive for subsidized users to install DG PV to offset their energy consumption and, therefore, reduce or eliminate the subsidies those customers receive. 
To install the first batch of PV DG systems, the government would need access to a large amount of capital, which may be one of the most important barriers for this program. Afterward, the savings from the subsidies and the payments from the users can be used to roll out the program to install more systems, adding additional savings in every stage of the process. According to calculations made by ICM, within only 7 years the avoided subsidies can be capable of supporting the whole mechanism, making it financially sustainable.

\subsubsection{Summary of Barriers}

- There is still uncertainty as to which customer classes, use characteristics, and locations would make for the best investment from the standpoint of the state

- Each individual customer has distinct usage

- Subsidized customers may be hesitant to lose their electricity subsidies, particularly if their PV DG system underperforms and does not provide expected savings

- Many subsidized customers do not have roof space or land or the right conditions to host a solar system. Without a community solar option, this program could exclude many customers.

\subsection{Establish Clearly Defined Role of CFE for DG}

Around the world, there are ongoing discussions about the evolving role of the distribution utility, given the substantial permeation of new and innovative technologies, including distributed energy resources such as DG. This has proven to be not only an extremely controversial and complex topic to explore, but is also highly localized to each specific utility context.

Rather than offer international experiences and discuss barriers and opportunities, the authors instead will offer a non-exhaustive list of ideas which describe, at a high-level, pathways that CFE may take, with respect to DG.

- CFE continues with business-as-usual model as only facilitating interconnection

- CFE requests incremental regulatory shifts to preserve revenue sufficiency (such as moving to value-based remuneration, revenue decoupling, performance-based regulatory frameworks, etc.)

- CFE becomes a DG installer which competes directly with the private sector for customers

- CFE becomes a DG installer which competes directly with the private sector for customers only in certain market segments (e.g., only residential customers, or only for shared solar)

- CFE becomes a DG "facilitator" that works with the private sector and facilitates competition on behalf of DG system owners to drive down prices

- CFE centrally administers a government incentive program (such as "Bono Solar")

- CFE rents rooftops from subsidized customers and installs/owns/operates DG systems 
- What research questions might need to be explored in advance of any large-scale change to the utility business model?

Resolving the ultimate role and business model of CFE Distribution could strengthen DG deployment in the long term by removing disincentives for the utility. 


\section{Appendix: Retail Rates in Mexico}

The public service retail rates in Mexico are divided by sector and voltage level. Other factors that affect the rates are location, temperature zones, and consumption levels. For DG projects interconnected at low and medium voltage levels, there are six main consumer groups divided as follows:

Table 6. Retail rates in Mexico according to the voltage level of the network that serves them

\begin{tabular}{|l|c|c|}
\hline \multirow{2}{*}{ Customer class } & \multicolumn{2}{|c|}{ Voltage Level } \\
\cline { 2 - 3 } & Low & Medium \\
\hline Residential & $1-1 \mathrm{~F}$ and DAC & \\
\hline Public Service & $5,5 \mathrm{~A}$ and 6 & 5 and $5 \mathrm{~A}$ \\
\hline Agricultural & $9,9 \mathrm{CU}$ and $9 \mathrm{~N}$ & $9 \mathrm{M}, 9 \mathrm{CU}$ and $9 \mathrm{~N}$ \\
\hline Commercial & 2 and 3 & \\
\hline Medium size industry & & OM and HM \\
\hline
\end{tabular}

A new retail rate scheme was implemented for all sectors (commercial and industrial) except residential customers at the end of 2017 (CFE 2017). ${ }^{24}$ This appendix does not reflect those changes.

\section{Residential}

There are eight residential rates in Mexico. Residential retail rates (1-1F) vary according to location based upon the minimum median temperature during the summer, establishing differentiated consumption limits for warmer locations to compensate for additional air conditioning usage. Customers that exceed the average monthly consumption for their location are charged a high consumption rate (DAC). Rates 1 to $1 \mathrm{~F}$ are heavily subsidized. Even though DAC customers have a strong incentive to invest in DG, they are a relatively small group, representing $1 \%$ of all residential electricity users (Table 7 ).

\footnotetext{
${ }^{24}$ See: Nuevo esquema tarifario (Diciembre 2017-2018)
} 
Table 7. Residential retail rate, annual information for 2016

\begin{tabular}{|l|c|c|c|c|}
\hline Rate & $\begin{array}{c}\text { Consumption Limit } \\
(\mathrm{kWh} / \mathrm{month})\end{array}$ & Users & $\begin{array}{c}\text { Sales } \\
(\mathrm{MWh})\end{array}$ & $\begin{array}{c}\text { Average Rate } \\
(\text { Pesos/kWh })\end{array}$ \\
\hline 1 & $<250$ & $19,633,299$ & $20,091,971$ & 1.07 \\
\hline $1 \mathrm{~A}\left(25^{\circ}\right)$ & $<300$ & $2,670,638$ & $2,855,949$ & 1.05 \\
\hline $1 \mathrm{~B}\left(28^{\circ}\right)$ & $<400$ & $4,027,974$ & $5,968,582$ & 1.07 \\
\hline $1 \mathrm{C}\left(30^{\circ}\right)$ & $<850$ & $5,690,081$ & $13,052,894$ & 1.16 \\
\hline $1 \mathrm{D}\left(31^{\circ}\right)$ & $<1000$ & $1,167,397$ & $3,172,795$ & 1.15 \\
\hline $1 \mathrm{E}\left(32^{\circ}\right)$ & $<2000$ & $1,188,866$ & $4,032,808$ & 0.96 \\
\hline $1 \mathrm{~F}\left(33^{\circ}\right)$ & $<2500$ & $1,308,591$ & $6,642,784$ & 0.93 \\
\hline $\mathrm{DAC}$ & High Consumption & 427,097 & $2,550,346$ & 3.44 \\
\hline
\end{tabular}

Source: Sistema de Información Energética

Residential rates have an inclining block structure with distinct levels that depend on the season (winter or summer). Summer inclining block rates from September 2015 are shown as an example below.

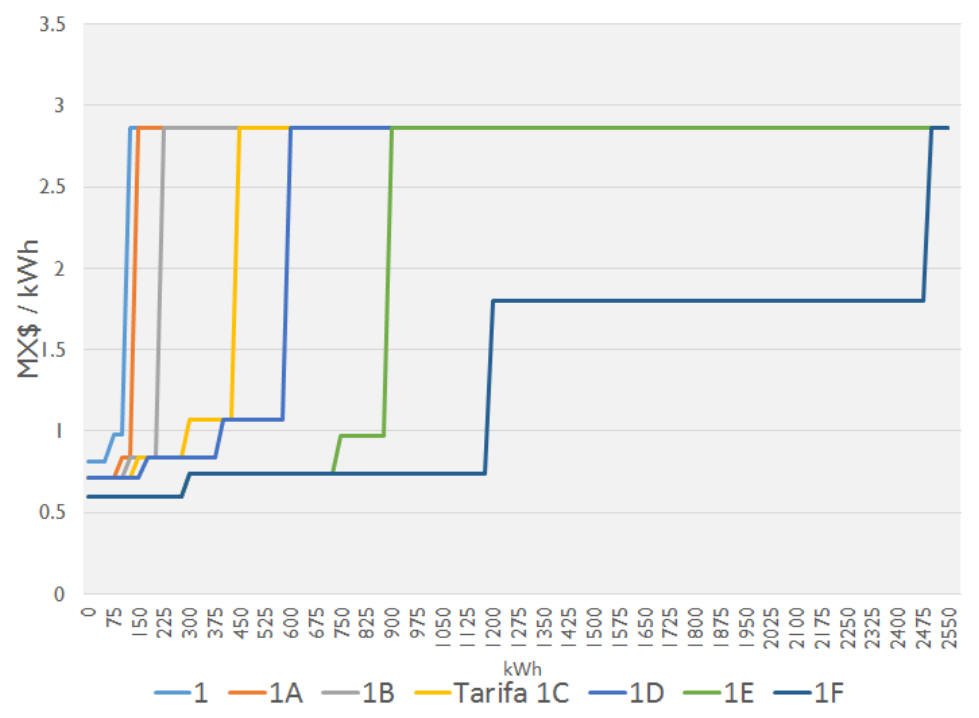

Figure 9. Residential tariff inclining block structure, Summer 2015.

Because of this inclining block structure, higher use residential customers see a stronger economic incentive to invest in DG than lower use residential customers within the same tariff class.

\section{Public Services}

Public services rates (shown in Table 8) include services for stop lights, public lighting and common areas and are categorized as rate 5 (for Mexico City, Guadalajara and Monterrey) and 5A (for the rest of the country). Customers in rate 5 are not subsidized and pay an average tariff rate of 3.60 pesos/kWh. Like DAC customers, this higher rate provides a strong economic signal to invest in DG, and has thus sparked interest in exploring DG projects in common areas such as 
apartment building gardens. Rate 6 applies to pumping drinking or sewage water, and includes a monthly minimum and additional charges for demand and energy consumed.

Table 8. Public Services rates in 2016

\begin{tabular}{|l|c|c|c|c|}
\hline Rate & $\begin{array}{c}\text { Demand } \\
\text { Charge }\end{array}$ & Users & $\begin{array}{c}\text { Sales } \\
\mathbf{( M W h )}\end{array}$ & $\begin{array}{c}\text { Average } \\
\text { Rate } \\
\text { (Pesos/kWh) }\end{array}$ \\
\hline 5 & No & 11,440 & $1,214,674$ & 3.60 \\
\cline { 3 - 5 } & & 161,990 & $3,943,531$ & 2.98 \\
\hline 6 & Yes & 35,957 & $3,485,006$ & 2.01 \\
\hline
\end{tabular}

Source: Sistema de Información Energética

\section{Agriculture}

Agriculture rates are applied to the energy needed to pump water for irrigating lands used for cultivation and the energy needed for public lighting where the pumping equipment is situated. Rates 9 and 9M have an inclining block structure, although it is not as steep as is the case for residential rates. As shown in Table 9, most users and sales are found in rates 9CU (daytime stimulus) and $9 \mathrm{~N}^{25}$ (night stimulus), which are highly subsidized rates up to a quota established by the Ministry of Agriculture, Livestock, Rural Development, Fisheries and Food. ${ }^{26}$

Table 9. Agricultural rates 2016

\begin{tabular}{|l|c|c|c|c|c|}
\hline \multirow{2}{*}{ Rate } & Description & \multirow{2}{*}{ Voltage } & Users & $\begin{array}{c}\text { Sales } \\
\mathbf{( M W h}\end{array}$ & $\begin{array}{c}\text { Average Rate } \\
\text { (Pesos/kWh) }\end{array}$ \\
\hline 9 & \multirow{2}{*}{ Agricultural Pumping } & Low & 7,757 & 46,899 & 2.76 \\
\cline { 1 - 4 } & & Medium & 8,499 & 393,801 & 2.18 \\
\hline $9 \mathrm{M}$ & Daytime Stimulus & \multirow{2}{*}{ Low and Medium } & 48,059 & $1,430,760$ & 0.62 \\
\cline { 1 - 3 } & Night Stimulus & & 64,250 & $9,456,363$ & 0.50 \\
\hline
\end{tabular}

Source: Sistema de Información Energética

\section{Commercial}

Commercial rates 2 and 3 are applicable to general services interconnected in low voltage. These rates are not subsidized, and customers pay on average 2.91 and 2.42 pesos/kWh respectively. Both are currently an attractive market for DG, although rate 2 is more attractive for developers because of the number of customers under this rate coupled with the relatively high cost per $\mathrm{kWh}$ (Table 10).

Table 10. Commercial rates, 2016

\begin{tabular}{|c|c|c|c|c|c|c|}
\hline Rate & Demand Limit & Fix Charge & $\begin{array}{l}\text { Demand } \\
\text { Charge }\end{array}$ & Users & $\begin{array}{c}\text { Sales } \\
\text { (MWh) }\end{array}$ & $\begin{array}{c}\text { Average Rate } \\
\text { (Pesos/kWh) }\end{array}$ \\
\hline 2 & up to $25 \mathrm{~kW}$ & Yes & \multirow{2}{*}{ Yes } & $3,964,914$ & $13,746,316$ & 2.91 \\
\hline 3 & above $25 \mathrm{~kW}$ & No & & 20,224 & $1,572,596$ & 2.42 \\
\hline
\end{tabular}

Source: Sistema de Información Energética

\footnotetext{
25 This rate has the highest subsidy for all sectors and is where most of the consumption takes place in the agricultural sector. In most cases, subsidies eliminate the price signals needed for efficient investments, but in this particular case, the government stimulus might provide other incentives such as protecting water resources and benefiting activities that can take place at night in base load hours.

${ }^{26}$ Secretaría de Agricultura, Ganadería, Desarrollo Rural, Pesca y Alimentación (SAGARPA)
} 


\section{Medium-scale industry}

Medium-scale industry rates OM and HM are applicable to general services interconnected in medium voltage. Although rates are not subsidized, customers pay on average 1.82 and 1.35 pesos/kWh respectively, making DG deployment less economically attractive compared to Residential DAC and Commercial rates (Table 11).

Table 11. Medium size industry rates, 2016

\begin{tabular}{|l|c|c|c|c|c|c|}
\hline Rate & Demand Limit & Rate Structure & $\begin{array}{c}\text { Demand } \\
\text { Charge }\end{array}$ & Users & $\begin{array}{c}\text { Sales } \\
\text { (MWh) }\end{array}$ & $\begin{array}{c}\text { Average Rate } \\
\text { (Pesos/kWh) }\end{array}$ \\
\hline OM & Up to $100 \mathrm{~kW}$ & By region & Yes & 236,410 & $14,903,129$ & 1.82 \\
\hline HM & Above $100 \mathrm{~kW}$ & By region & Yes & 88,355 & $68,330,448$ & 1.35 \\
\hline
\end{tabular}

Source: Sistema de Información Energética 


\section{References}

ANCE. 2012. ANCE-ESP-02 Especificaciones Técnicas de Seguridad y Funcionamiento de Proyectos e Instalaciones de Sistemas Fotovoltaicos. Asociación de Normalización y Certificación, A.C. http://portal.infonavit.org.mx/wps/wcm/connect/4ad1c4b6-fc3c-4a2d-a80f3f30de088544/ANCE-ESP02+Especificaciones+t\%C3\%A9cnicas+de+Sistemas+Fotovoltaicos.pdf?MOD=AJPERES\&CO NVERT_TO=url\&CACHEID=ROOTWORKSPACE-4ad1c4b6-fc3c-4a2d-a80f-3f30de088544$\underline{\underline{\operatorname{Ir} 9 \mathrm{a} A \mathrm{~B}}}$

ANCE. 2017. Padrón de Empresas. Asociación de Normalización y Certificación, A.C. http://www.ance.org.mx/SistemaHipotecaVerde/Padron.aspx\#

Bird, L., McLaren, J., Heeter, J., Linvill, C., Shenot, J., Sedano, R., Migden-Ostrander, J. 2013. Regulatory Considerations Associated with the Expanded Adoption of Distributed Solar. NREL/TP-6A20-60613. Golden, CO: National Renewable Energy Laboratory and Regulatory Assistance Project. http://www.nrel.gov/docs/fy14osti/60613.pdf.

Chacón n.d. Los Beneficios de la DG y GDL. https://www.gob.mx/cms/uploads/attachment/file/181536/Daniel_Chacon.pdf

Clean Energy States Alliance (CESA). 2016. A Directory of State Clean Energy Programs and Policies for Low-Income Residents. http://cesa.org/resource-library/resource/directory-of-stateclean-energy-programs-and-policies-for-low-income-residents

Comisión Federal de Electricidad (CFE). 2017. "Nuevo esquema tarifario (Diciembre 20172018). https://app.cfe.mx/Aplicaciones/CCFE/Tarifas/TarifasCREIndustria/Industria.aspx

CONAVI. 2016. Mejoramiento Integral Sustentable en Vivienda. Comisión Nacional de Vivienda. https://www.gob.mx/cms/uploads/attachment/file/133280/INFO-sustentabilidadok.pdf

CONOCER. 2015a. Acuerdo SO/II-15/10.02,S del H. Comité Técnico del Consejo Nacional de Normalización y Certificación de Competencias Laborales, por el que se aprobaron los Estándares de Competencia que se indican. Diario Oficial de la Federación. http://dof.gob.mx/nota_detalle.php?codigo=5396211\&fecha=11/06/2015

CONOCER. 2015b. Estándar de Competencia EC0586 Instalación de sistemas fotovoltaicos en residencia, comercio e industria. Comité Técnico del Consejo Nacional de Normalización y Certificación de Competencias Laborales. http://www.conocer.gob.mx/publicaciones_dof/EC0586.pdf

CONOCER. 2016. Qué hacemos en el CONOCER. Comité Técnico del Consejo Nacional de Normalización y Certificación de Competencias Laborales.

http://www.conocer.gob.mx/pdfs/documentos/que_hacemos_conocer.pdf 
CONUEE. 2017. Normas mexicanas Generación distribuida. Comisión Nacional para el Uso Eficiente de la Energía. http://www.gob.mx/conuee/acciones-y-programas/normas-mexicanasgeneracion-distribuida-estados-y-municipios?state=published

Cook, J. 2016. "Understanding Some Key Differences in Community Solar Policy across the States.” June 2, 2016. National Renewable Energy Laboratory. https://www.nrel.gov/tech_deployment/state_local_governments/blog/understanding-some-keydifferences-in-community-solar-policy-across-the-states

Coughlin, Jason, Jennifer Grove, Linda Irvine, Janet F. Jacobs, Sarah Johnson Phillips, Alexandra Sawyer, Joseph Wiedman. 2012. A Guide to Community Shared Solar: Utility, Private, and Nonpro-fit Project Development. NREL (National Renewable Energy Laboratory). http://www.nrel.gov/docs/fy12osti/54570.pdf

Cox, Sadie. 2016. Financial Incentives to Enable Clean Energy Deployment. Clean Energy Solutions Center. http://www.nrel.gov/docs/fy16osti/65541.pdf

CRE. 2010. RES/054/2010 Resolución por la que la Comisión Reguladora de Energía expide el Modelo de Contrato de Interconexión para Fuente de Energía Renovable o Sistema de Cogeneración en Mediana Escala, y sustituye el Modelo de Contrato de Interconexión para Fuente de Energía Solar en Pequeña Escala por el Modelo de Contrato de Interconexión para Fuente de Energía Renovable o Sistema de Cogeneración en Pequeña Escala. Diario Oficial de la Federación. http://dof.gob.mx/nota_detalle_popup.php?codigo=5137984

CRE. 2012. RES/249/2012 Resolución por la que la Comisión Reguladora de Energía aprueba y expide el modelo de contrato de interconexión para fuente colectiva de energía renovable o sistema colectivo de cogeneración eficiente en pequeña escala. Diario Oficial de la Federación. http://dof.gob.mx/nota_detalle.php?codigo=5264819\&fecha=21/08/2012

CRE. 2016. Contratos de interconexión en pequeña y mediana escala: Estadísticas ejercicio 2016. Comisión Reguladora de Energía. https://www.gob.mx/cms/uploads/attachment/file/197773/CIPME_Estad_sticas_2016.pdf CRE. 2017a. Contractos de Interconexión en pequeña y mediana escala. Estadísticas ejercicio 2017 (1er semestre). https://www.gob.mx/cms/uploads/attachment/file/257978/CIPME_Estad_sticas_2017_1er_sem estre.pdf

CRE. 2017b. RES/142/2017 Resolución de la Comisión Reguladora de Energía por la que expide las disposiciones administrativas de carácter general, los modelos de contrato, la metodología de cálculo de contraprestación y las especificaciones técnicas generales, aplicables a las centrales eléctricas de generación distribuida y generación limpia distribuida. Diario Oficial de la Federación. http://www.dof.gob.mx/nota_detalle.php?codigo=5474790\&fecha=07/0v3/2017

Denholm, Paul, Robert Margolis, Bryan Palmintier, Clayton Barrows, Eduardo Ibanez, Lori Bird, and Jarett Zuboy. 2014. Methods for Analyzing the Benefits and Costs of Distributed Photovoltaic Generation to the U.S. Electric Utility System. NREL/TP-6A20-62447. Golden, CO: National Renewable Energy Laboratory. http://www.nrel.gov/docs/fy14osti/62447.pdf 
DOE. n.d. "Revolving Loan Funds.” State and Local Solutions Center.

https://www.energy.gov/eere/slsc/revolving-loan-funds

DOE 2016. New Analysis Shows National Potential for Solar Power in Low-Income Communities. https://energy.gov/eere/articles/new-analysis-shows-national-potential-solarpower-low-income-communities

DOF. 2014. Ley de la Industria Eléctrica. Diario Oficial de la Federación. http://www.dof.gob.mx/nota_detalle.php?codigo=5355986\&fecha=11/08/2014

DOF. 2015. Ley de Transición Energética. Diario Oficial de la Federación. Diario Oficial de la Federación. http://dof.gob.mx/nota_detalle.php?codigo=5421295\&fecha=24/12/2015

DSIRE 2017, Database of State Incentives for Renewables \& Efficiency, http://www.dsireusa.org/

Eberhard, A., Kolker, J., Leigland, J. South Africa’s Renewable Energy IPP Procurement Program: Success factors and Lessons. Public-Private Infrastructure Advisory Facility (PPIAF). http://www.gsb.uct.ac.za/files/ppiafreport.pdf

Feldman, David and Travis Lowder. 2014. Banking on Solar: An Analysis of Banking Opportunities in the U.S. Distributed Photovoltaic Market. Golden, CO. National Renewable Energy Laboratory. Accessed on January 15, 2016. http://www.nrel.gov/docs/fy15osti/62605.pdf

FIDE. 2016. Los Apoyos del FIDE a la Industria Mexicana. Fideicomiso para el Ahorro de la Energía Eléctrica.

https://www.canacintra.org.mx/presentaciones/2016_mayo/foro_energia/PANEL\%20IV\%202\% 20PONENCIA\%20DE\%20RUBEN\%20ZAGAL\%20LEON\%20\%20CANACINTRA\%2020\%2 0MAYO\%202016.pdf

FIDE. 2017a. Programa de Apoyo a la Generación Distribuida. Fideicomiso para el Ahorro de la Energía Eléctrica.

http://www.fide.org.mx/index.php?option=com_content\&view=article\&id=658\&Itemid=283

FIDE. 2017b. Personas Certificadas en el Estándar de Competencia EC-0586 "Instalación de Sistemas Fotovoltaicos en Residencia, Comercio e Industria". Fideicomiso para el Ahorro de la Energía Eléctrica.

http://www.fide.org.mx/index.php?option=com_content\&view=article\&id=667\&Itemid=224

FIRCO. 2012. Informe de Rendición de Cuentas 2006-2012. Fideicomiso de Riesgo Compartido. http://www.firco.gob.mx/POTTtransparencia/Documents/MemoriasDocumentales/firco_md_ene rgia_renovable.pdf

FIRCO. 2016. Sagarpa a través de Firco apoya agroproductores para la instalación de sistemas fotovoltaicos. Fideicomiso de Riesgo Compartido. https:/www.gob.mx/firco/prensa/sagarpa-atraves-de-firco-apoya-agroproductores-para-la-instalacion-de-sistemas-fotovoltaicos?idiom=es 
GTM/SEIA (GTM Research and the Solar Energy Industries Association). 2017. U.S.

Solar Market Insight. https://www.greentechmedia.com/research/report/us-solar-

market-insight-2017-year-in-review.

Honeyman, C., Shiao, M., Krulewitz, S. 2017. U.S. Community Solar Market Outlook 2017. GTM Research. http://www.greentechmedia.com/research/report/us-communitysolar-market-outlook-2015-2020

Holt, E., Sumner, J., Bird, L. 2011. The Role of Renewable Energy Certificates in Developing New Renewable Energy Projects. NREL. http://www.nrel.gov/docs/fy11osti/51904.pdf

International Energy Agency (IEA). 2016. "Policies and Measures: Germany.” https://www.iea.org/policiesandmeasures/pams/germany/name-25107-en.php

IFC. 2012a. “Public-Private Partnership Stories: India: Gujarat Solar.” Washington, D.C.: International Finance Corporation.

http://www.ifc.org/wps/wcm/connect/d0a75c804b077348b4acfe888d4159f8/PPPStories_India GujaratSolar.pdf?MOD=AJPERES.

John, J. 2016. Breaking: California’s NEM 2.0 Decision Keeps Retail Rate for Rooftop Solar, Adds Time-of-Use. January, 28, 2016. GreenTech Media.

https://www.greentechmedia.com/articles/read/californias-net-metering-2-0-decision-rooftopsolar-to-keep-retail-payme

Linvill, C., Brutkoski, D. 2017. Designing Distributed Generation in Mexico. Regulatory Assistance Project. https://www.nrel.gov/docs/fy17osti/66026.pdf.

Lowder, Travis, Paul Schwabe, Ella Zhou and Doug Arent. 2015. Historical and Current U.S. Strategies for Boosting Distributed Generation. National Renewable Energy Laboratory (NREL). Accessed January 15, 2016. http://www.nrel.gov/docs/fy16osti/64843.pdf

Martinez, C. 2016. Mexican Tax Incentives for Green Energy Companies. Tax Notes International. Vol 83, Number 7. http://www.creelabogados.com/assets/PDF/Mexican-TaxIncentives-for-Green-Energy-Companies_TaxNotes_August2016.pdf

Minnesota Commerce Department. 2017. Made in Minnesota Solar Incentive Program. https://mn.gov/commerce/industries/energy/solar/mim/

National Grid. 2016. Implementation Plan for Fruit Belt Neighborhood Solar REV Demonstration in Buffalo, New York. National Grid. http://documents.dps.ny.gov/public/Common/ViewDoc.aspx?DocRefId=\%7BAFABE824-60F54800-9D28-5FC1A69B4D83\%7D.

National Renewable Energy Laboratory, 2017. Low-and Moderate-Income Solar Policy Basics. https://www.nrel.gov/technical-assistance/lmi-solar.html

National Renewable Energy Laboratory.n.d. Green Banks. https://www.nrel.gov/technicalassistance/basics-green-banks.html 
NL Energy. 2010. The Green Funds Scheme: A success story in the making. Commissioned by the Ministry of Housing, Spatial Planning and Environment. https://www.rvo.nl/sites/default/files/bijlagen/SEN040\%20DOW\%20A4\%20Greenfunds_tcm24119449.pdf

RES LEGAL. 2017. Legal Sources on Renewable Energy. http://www.res-legal.eu/

Rodríguez, Jessica. 2017. "Reporte de Avances de Energías Limpias, Al Primer Semestre de 2017.” SENER. Presentation for the "Consejo Consultivo para la Transición Energética." December 11, 2017.

Ross, Sara. 2015. Solar loans should be more like car sales or cable television services. Greentech Media. Podcast with Sungage Financial. Accessed January 16, 2015. http://www.greentechmedia.com/articles/read/solar-loans-should-pv-be-more-like-car-sales-orcable-television-services

SAGARPA. 2016. Acuerdo por el que se dan a conocer las Disposiciones Generales aplicables a las Reglas de Operación de los Programas de la Secretaría de Agricultura, Ganadería, Desarrollo Rural, Pesca y Alimentación, para el ejercicio 2017. Diario Oficial de la Federación. http://www.gob.mx/cms/uploads/attachment/file/199203/Reglas_de_Operaci_n_del_PFA_de_la_ SAGARPA-DOF-31.12.2016.pdf

SAGARPA/FIRCO. 2017. Incorporación de Empresas Verificadas. Proyecto de Energía Renovable. http://www.proyectodeenergiarenovable.com/

SE Secretaría de Economía. 2017. Normas Mexicanas. http://www.economianmx.gob.mx/normasmx/index.nmx

SE. 2016. Estrategia para el Fomento Industrial de Cadenas Productivas Locales y para el Fomento de la Inversión Directa en la Industria Eléctrica y Energías Limpias. Secretaría de Economía. https://proenergia.economia.gob.mx/fideicomiso/app/publicDocument/download/2f436f6e766f6 361746f726961732f457374726174656769615f456c656374726963696461642e706466

SE. 2016b. Reglas de Operación del FIDEICOMISO Público para promover el desarrollo de Proveedores y Contratistas Nacionales de la Industria Energética. Secretaría de Economía. http://www.gob.mx/cms/uploads/attachment/file/169795/Reglas_de_Operaci_n_2016_VF_Nov. pdf

SENER/CONUEE. 2016. Estrategia de Transición para Promover el Uso de Tecnologías y Combustibles más Limpios. Secretaría de Energía y Comisión Nacional para el Uso Eficiente de la Energía.

https://www.gob.mx/cms/uploads/attachment/file/182202/20161110_1300h_Estrategia_CCTE1.pdf

SENER. 2016a. Programa de Desarrollo del Sistema Eléctrico Nacional 2016-2030, PRODESEN. Secretaría de Energía. http://www.gob.mx/sener/acciones-y-programas/programade-desarrollo-del-sistema-electrico-nacional-33462 
SENER. 2016b. Programa de Redes Eléctricas Inteligentes, PRODERI. Secretaría de Energía. http://www.gob.mx/cms/uploads/attachment/file/90007/Programa_de_Redes_El_ctricas_Intelige ntes_09_05_16.pdf

SENER. 2016c. Acuerdo por el que se emite el Manual de Interconexión de Centrales de Generación con Capacidad menor a 0.5 MW. Secretaría de Energía. http://www.dof.gob.mx/nota_detalle.php?codigo=5465576\&fecha=15/12/2016

SENER 2017a. Primer análisis sobre los beneficios de la generación limpia distribuída y la eficiencia energética en México.

https://www.gob.mx/cms/uploads/attachment/file/201875/Beneficios_de_la_GLD_y_EE_en_Me xico.pdf

SENER. 2017b. Programa Especial de la Transición Energética 2017-2018, PETE. Secretaría de Energía. http://www.gob.mx/cms/uploads/attachment/file/213322/PETE.pdf

SENER. 2017c. Programa de Desarrollo del Sistema Eléctrico Nacional 2017-2030, PRODESEN. Secretaría de Energía.

http://base.energia.gob.mx/prodesen/PRODESEN2017/PRODESEN-2017-2031.pdf

Speer, B., and Koenig, R. 2010. Property-Assessed Clean Energy (PACE) Financing of Renewables and Efficiency. NREL (National Renewable Energy Laboratory).

http://www.nrel.gov/docs/fy10osti/47097.pdf

Sustainability Roundtable Inc. 2012. International Markets for Renewable Energy Certificates (RECs).

http://sustainround.com/library/sites/default/files/SRER_Member\%20Briefing_International\%20 Markets\%20for\%20Renewable\%20Energy\%20Certificates_2012-07-16.pdf

U.S. Department of Health and Human Services. 2015. Renewable Energy and LIHEAP: Solar Projects Target Energy Burdens. LIHEAP Clearing House.

https://liheapch.acf.hhs.gov/pubs/LCIssueBriefs/solar/renewable.pdf

Woolf, Tim, Melissa Whited, Patrick Knight, Tommy Vitolo, and Kenji Takahashi. 2016. Show Me the Numbers: A Framework for Balanced Distributed Solar Policies. Prepared for Consumers Union. Cambridge, MA: Synapse Energy Economics.

http://www.synapseenergy.com/project/show-me-numbers-framework-balanced-distributedsolarpolicies 